\title{
2-Styrylchromones
}

\section{An Overview of 2-Styrylchromones: Natural Occurrence, Synthesis, Reactivity and Biological Properties}

\author{
Clementina M. M. Santos ${ }^{[a, b]}$ and Artur M. S. Silva* ${ }^{* b]}$
}

Abstract: 2-Styrylchromones are a small class of oxygen-containing heterocycles. Despite their sparse occurrence in nature, several synthetic approaches have been developed in order to synthesize a large variety of derivatives, possessing different substituents in different positions of the main core. They are also versatile building blocks in the synthesis of new hetero- cyclic systems and important intermediates in the search for bioactive compounds. It is our intention in this review to give a general overview on the natural occurrence, synthesis, reactivity and biological properties of 2-styrylchromones, which were published up until 2016.

\section{Introduction}

4H-Chromen-4-ones, or simply chromones (cf. the A component in structure 1, Figure 1), a well-known class of oxygenated heterocyclic compounds, play an important role in nature due to their recognized biological, pharmacological and biocidal activities. $^{[1-3]}$ These effects of these naturally occurring compounds, associated with the large variety of substituents and positions in their skeleton, have resulted in strong demand over the years for their isolation in large amounts, for the development of efficient and eco-friendly routes for their synthesis, as

[a] School of Agriculture, Polytechnic Institute of Bragança,

Campus de Santa Apolónia, 5300-253 Bragança, Portugal

E-mail: clems@ipb.pt

[b] Department of Chemistry, QOPNA \&University of Aveiro,

Campus de Santiago

3810-193 Aveiro, Portugal

E-mail: artur.silva@ua.pt

https://sites.google.com/site/artursilvaua/

(D) ORCID(s) from the author(s) for this article is/are available on the WWW under http://dx.doi.org/10.1002/ejoc.201700003. well as the pursuit of new and more strongly bioactive analogues. Moreover, the chromone ring system is a valuable starting material in many chemical reactions leading to the preparation of a wide variety of synthetic derivatives, some of them used nowadays as therapeutic agents. ${ }^{[2,4]}$ It is therefore the alliance of chemistry and biological activities that forms the basis of this review, dedicated to the versatility of a small group of

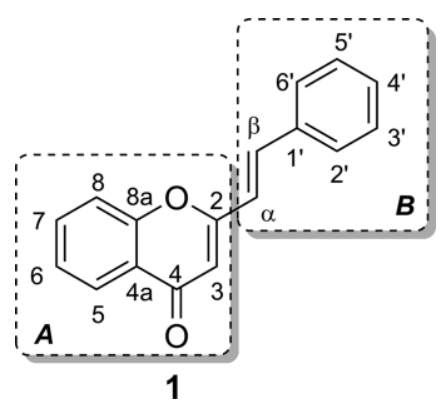

Figure 1. Structure and numbering system of 2-SC (1).
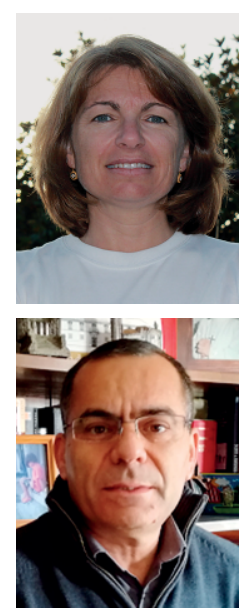

Dr. Clementina M. M. Santos graduated in chemistry (1996), obtained her Master in Sciences in the chemistry of natural products and foodstuffs (2000) and received her PhD in chemistry (2007), all at the University of Aveiro (Portugal). She began her career at the Institute Polytechnic of Bragança in 2000 as Assistant and was appointed Assistant Professor in 2010. She has published over 25 papers and nine book chapters. Her research interests range over the synthesis of heterocyclic compounds and evaluation of their biological properties, especially the antioxidant activity. 
chromones possessing a styryl moiety (B component in structure 1, Figure 1) at position 2 and known as 2-styrylchromones 1 [or (E)-2-styryl-4H-chromen-4-one, 2-SC, Figure 1]. Here we cover the sparse natural occurrence, synthesis, reactivity and biological profile of 2-styrylchromones in a a single and general overview intended to highlight better the importance of this small group of oxygen-containing heterocycles.

NMR spectroscopy has been the most powerful technique used for the structural elucidation of 2-SCs. The configuration and conformation of 2-SCs were established through the analysis of their 1D and 2D NMR spectra. The vicinal coupling constant $\left(J_{\mathrm{H} \alpha, \mathrm{H} \beta}\right)$ at about $15-17 \mathrm{~Hz}$ indicates a trans configuration for the double bond in all known natural 2-SC derivatives and almost all the synthetic derivatives. ${ }^{[5-7]}$ In addition, NOE cross peaks observed between $\mathrm{H}-\alpha$ and $\mathrm{H}-3$ and the absence of cross peaks between $\mathrm{H}-\beta$ and $\mathrm{H}-3$ confirm that, in solution, parent 2SC (1) exists in a C2-C $\alpha$ s-trans conformation. The delocalized $\mathrm{C} 2=\mathrm{C} 3, \mathrm{C} \alpha=\mathrm{C} \beta$ doubly unsaturated carbonyl system implies that the $\mathrm{C} 2-\mathrm{C} \alpha$ bond has a character between a single and a double bond, preventing free rotation, and only the s-trans conformation was observed (Figure 2). ${ }^{[6]}$ These data were also confirmed by NOESY experiments with other substituted 2-SCs. ${ }^{[5,7-9]}$

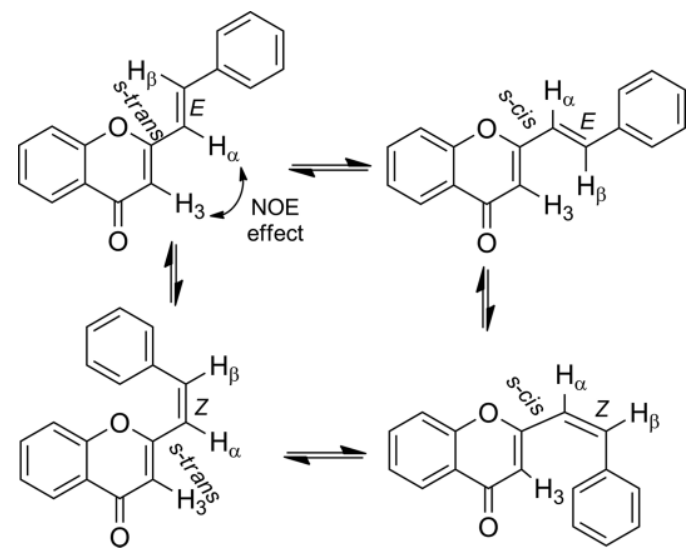

Figure 2. Four possible conformers of 2-SC and NOE effect in the E-s-trans conformer

The X-ray crystal structure of hormothamnione triacetate ${ }^{[10]}$ corroborates the $E$ configuration of the $C \alpha=C \beta$ double bond and the s-trans conformation of the $\mathrm{C} 2-\mathrm{C} \alpha$ bond in the solid state.

To simplify the manuscript, the $E$ configuration of $C \alpha=C \beta$ and the $\mathrm{C} 2-\mathrm{C} \alpha$ s-trans conformation of 2-SC is assumed unless the appropriate stereochemistry is specifically mentioned.

\section{Natural Occurrence of 2-Styrylchromones}

2-SCs are scarce in nature. Thirty years after the isolation of the first natural 2-SC - hormothamnione (2, Figure 3 ) - there is still no report that confirms the isolation of the parent compound 1 from natural sources. Hormothamnione (2) was first isolated in 1986, from a chloroform/methanol extract of cyanobacterium Hormothamnion enteromorphoides collected on the north coast of Puerto Rico. ${ }^{[10]}$ Three years later, Gerwick revised the taxonomy of the material collected to the Cryptophycean alga Chry- sophaeum taylori and even isolated the new, closely related derivative 6-desmethoxyhormotamnione (3, Figure 3). ${ }^{[1]}$ Yoon et al. obtained a new, less substituted natural 2-SC in the form of 5-hydroxylated derivative 4 (Figure 3), from the methanol extract of the rhizomes of Imperata cylindrica. ${ }^{[12]}$ The synthesis of $\mathbf{4}$ and its structural elucidation by NMR spectroscopy have been described previously by our group. ${ }^{[13]} 6,4^{\prime}$-Dihydroxy-3'methoxy-2-styrylchromone (5, Figure 3) was isolated from the ethanol extract of Chinese eaglewood as a yellow amorphous solid and fully characterized by NMR, MS and IR spectroscopy. ${ }^{[14]}$ In 2013, the five 5,7,4'-trihydroxy-2-styrylchromones 6-10 (Figure 3) were isolated from an ethanol extract of the shed bark of Platanus $x$ acerifolia. ${ }^{[15]}$ Meanwhile, derivative 6 has also been isolated from heartwood of Juniperus chinensis (by heating at reflux in methanol) ${ }^{[16]}$ and from an ethanol extract of the bulbils of Dioscorea bulbifera. ${ }^{[17]}$ It is also worth noting that compound $\mathbf{6}$ was synthesized by us prior to its isolation. ${ }^{[18]}$ Of compounds 7-10, named platachromones A-D, the prenylated analogue platachromone $B(\mathbf{8})$ has recently been synthesized by our group. ${ }^{[19]}$

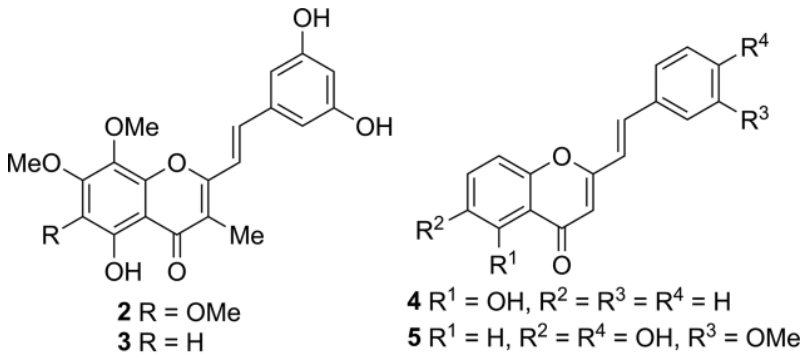

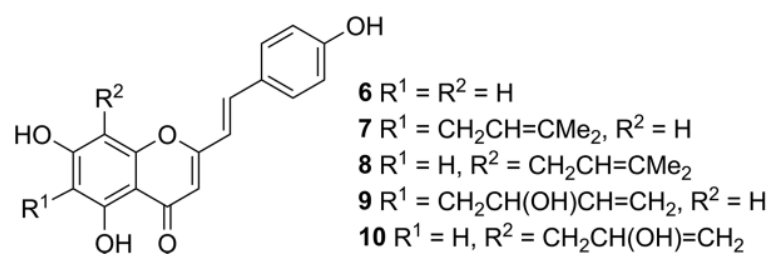

Figure 3. Structures of natural 2-SC derivatives 2-10.

\section{Synthesis of 2-Styrylchromones}

As far as we know, the synthesis of 2-SCs goes back to $1923,{ }^{[20]}$ and since then several approaches have been developed in order to prepare a wide variety of analogues. These approaches, also summarized in two previous papers, ${ }^{[21,22]}$ include: (1) cyclization of an acetylenic ketone, (2) Allan-Robinson condensation, (3) intramolecular Wittig reaction, (4) condensation of 2methylchromones with benzaldehydes, (5) aldol condensation followed by oxidative cyclization, and (6) Baker-Venkataraman rearrangement. It is our intention to describe these methodologies not chronologically but from the less frequently used to the most widely used ones.

\subsection{Cyclization of an Acetylenic Ketone}

A simple attempt using an acetylenic ketone in the synthesis of 2-ST was reported. Only parent 2-SC (1) was prepared, in a mul- 
tistep strategy involving the treatment of tetrahydro- $2 \mathrm{H}$-pyranyl-protected propargyl alcohol 11 with BuLi at $-78^{\circ} \mathrm{C}$, addition of cinnamaldehyde, oxidation and removal of the protecting group to afford the conjugated acetylenic ketone 12 in $81 \%$ yield. Subsequent $\mathrm{HBr}$-catalyzed cyclization in 1,4-dioxane at $80{ }^{\circ} \mathrm{C}$ provided the unsubstituted 2-SC (1) in $82 \%$ yield (Scheme 1). ${ }^{[23]}$

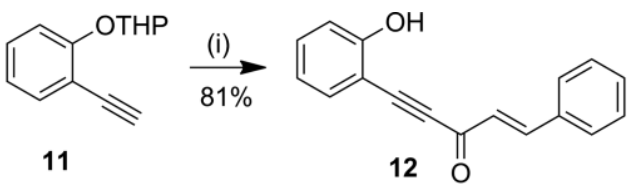

(i) 1. $n \mathrm{BuLi}, \mathrm{THF},-78^{\circ} \mathrm{C}$
2. $\mathrm{PhCH}=\mathrm{CHCHO}$
3. $\mathrm{MnO}_{2}, \mathrm{CH}_{2} \mathrm{Cl}_{2}, 0^{\circ} \mathrm{C}$
4. $\mathrm{PPTS}, \mathrm{EtOH}, 50^{\circ} \mathrm{C}$ (ii) $\mathrm{HBr}$ (aq.), 1,4-dioxane, $80^{\circ} \mathrm{C}$

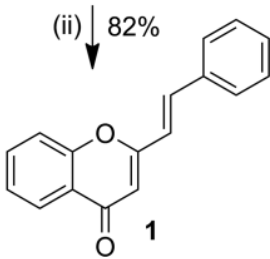

Scheme 1. Synthesis of parent 2-SC (1) through cyclization of an acetylenic ketone. THP $=$ tetrahydro- $2 \mathrm{H}$-pyranyl, PPTS $=$ pyridinium $p$-toluenesulfonate.

\subsection{Allan-Robinson Condensation}

The method developed by Allan and Robinson for the synthesis of flavones was applied for the first time in the synthesis of 2SC in 1925. Heating appropriate cinnamic anhydrides and the corresponding sodium cinnamates with 1-(2-hydroxyaryl)-2methoxyethan-1-ones at $180{ }^{\circ} \mathrm{C}$ led to the synthesis of a few 3methoxy-2-styrylchromones $13\left(R^{2}=\right.$ OMe, Scheme 2), which after methyl cleavage provided the corresponding 3-hydroxy-2styrylchromones. ${ }^{[24]}$ Years later other 3-unsubstituted $\left(\mathrm{R}^{2}=\mathrm{H}\right)$ and 3-methylated $\mathbf{1 3}\left(\mathrm{R}^{2}=\mathrm{Me}\right)$ derivatives were prepared by using similar conditions in the condensation reaction (Scheme 2). ${ }^{[25]}$ The mechanism involves a one-step cinnamoylation of a 2'-hydroxyacetophenone, rearrangement to a 2cinnamoyl-2'-hydroxyacetophenone and cyclization.<smiles>[R]CC(=O)c1cc[R1]([NH-])cc1O</smiles>

(i) $\mathrm{ArCH}=\mathrm{CHCO}_{2} \mathrm{Na}$ or $\mathrm{K}, 180-190^{\circ} \mathrm{C}, 3-8 \mathrm{~h}$ $\mathrm{R}^{1}=\mathrm{H}, \mathrm{OH}, \mathrm{CH}=\mathrm{CHPh}$ $\mathrm{R}^{2}=\mathrm{H}, \mathrm{Me}, \mathrm{OMe}$ $\mathrm{R}^{3}=\mathrm{H}, \mathrm{OMe}$<smiles>[R1]c1ccc(/C=C/C(=O)OC(=O)/C=C/c2ccc([Y10])cc2)cc1</smiles><smiles>[R]c1ccc(/C=C/c2oc3cc([R1])ccc3c(=O)c2[R])cc1</smiles>

Scheme 2. Synthesis of 2-SCs 13 through Allan-Robinson condensation.

\subsection{Intramolecular Wittig Reaction}

Only two publications have reported the synthesis of 2-SCs through condensation of (2-hydroxybenzylidene)triphenylphosphoranes with cinnamoyl chloride. In the first one, 1-(2hydroxyphenacylidene)triphenylphosphorane $\left(15, R^{1}=R^{2}=\right.$ $R^{3}=H$ ), prepared through the reaction between 2-acetoxyphenacyl bromide (14) and triphenylphosphine, followed by ester hydrolysis, underwent condensation with cinnamoyl chloride in the presence of pyridine and toluene at reflux. ${ }^{[26]}$ The formed o-cinnamoyl ester $16\left(R^{1}=R^{2}=R^{3}=H\right)$ underwent an intramolecular Wittig reaction to give the parent 2-SC, in $65 \%$ yield. The second approach is a more general strategy and involves reactions between [1-(2-hydroxybenzoyl)alkylidene]triphenylphosphoranes 15 (obtained by condensation of methyl 2-hydroxybenzoates $\mathbf{1 7}$ withsubstitutedtriphenylphosphines)and cinnamoyl chloride in dry pyridine at $60{ }^{\circ} \mathrm{C}$ for $24 \mathrm{~h}$ (Scheme 3). A range of substituted 2-SCs 18 were prepared in 47-70\% yields. ${ }^{[27]}$

\subsection{Condensation between 2-Methylchromones and Benzaldehydes}

One of the oldest approaches to the synthesis of 2-SCs consists of base-promoted condensation between 2-methylchromones and benzaldehydes. In 1923, Heilbron et al. reported the first

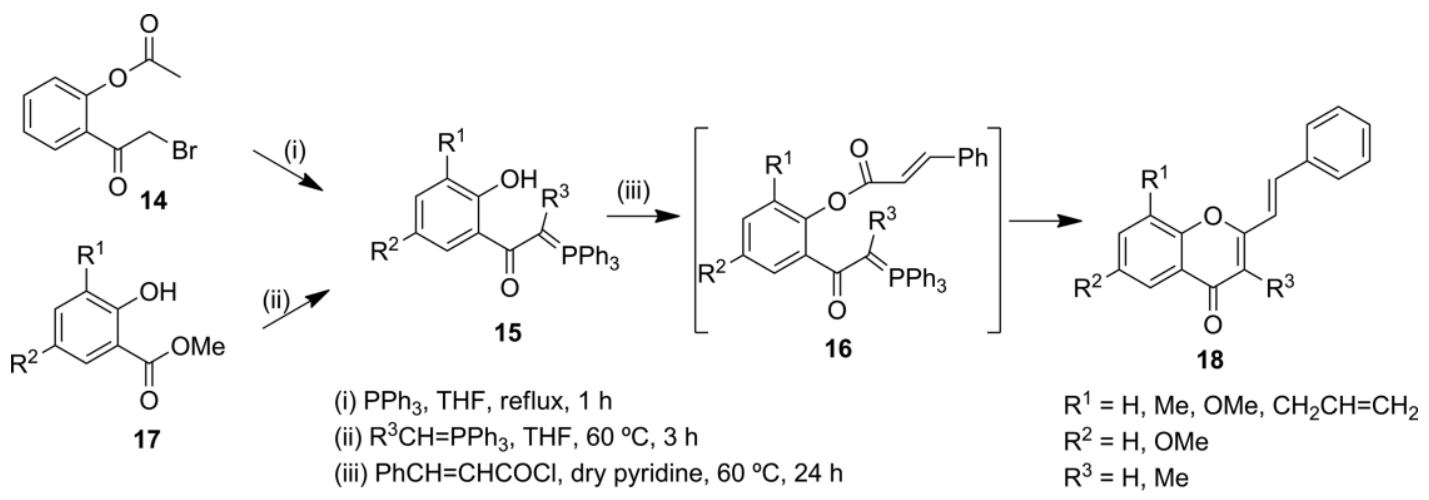

Scheme 3. Synthesis of 2-SCs 18 through intramolecular Wittig reactions. 
synthesis of various 3-methyl-2-styrylchromones 19 by condensation of 2,3-dimethylchromone with a variety of substituted benzaldehydes in the presence of sodium ethoxide in ethanol at room temperature for $24 \mathrm{~h}$ (Scheme 4). ${ }^{[20]}$ Naturally occurring hormothamnione (2) was synthesized both by this strategy, ${ }^{[28]}$ and also in the presence of sodium methoxide in methanol at reflux. ${ }^{[29,30]}$ Under the latter conditions, some 3-methylated and 3-unmethylated (2-styrylchromon-8-yl)acetic acids arose in 7-24 $\mathrm{h}$ in $40-55 \%$ yields. $^{[5]}$ A couple of 3-bromo-2-styrylchromones $\mathbf{2 0}$ were prepared by condensation of 3-bromo-2methylchromone with benzaldehyde/4-benzyloxybenzaldehyde in the presence of sodium methoxide in methanol at room temperature, in good yields (Scheme 4). ${ }^{[31]}$ Under the same reaction conditions, the condensation of 2-methyl-3-styrylchromones with parent benzaldehyde provided a few examples of 2,3distyrylchromones 21. ${ }^{[32]}$ Condensation between 2-methyl-3-<smiles>[R][R]c1cccc(/C=C/c2oc3ccccc3c(=O)c2C)c1</smiles><smiles>[R][R]1cccc(/C=C/c2c(/C=C/c3ccccc3)oc3ccccc3c2=O)c1</smiles><smiles>[R][R]c1cccc(/C=C/c2oc3c[Z10](C(C)(C)C)ccc3c(=O)c2[N+](=O)[O-])c1</smiles><smiles>[R]c1ccc(/C=C/c2cc(=O)c3cc[Z10]([O-])cc3o2)cc1</smiles>

$\mathrm{R}^{1}=\mathrm{H}, \mathrm{Br}, \mathrm{Me}, \mathrm{OBn}, \mathrm{OEt}, \mathrm{OMe}, \mathrm{OPr}, p$-methoxybenzyloxy, $\mathrm{CH}_{2} \mathrm{~N}\left\{\left[\left(\mathrm{CH}_{2}\right)_{2} \mathrm{Ph}\right]\left[\mathrm{CH}_{2}(p-\mathrm{OMe}) \mathrm{Ph}\right]\right\},-\mathrm{OCH}=\mathrm{CH}-$

$\mathrm{R}^{2}=\mathrm{H}, \mathrm{Br}, \mathrm{CF}_{3}, \mathrm{Cl}, \mathrm{F}, \mathrm{Me}, \mathrm{NMe}_{2}, \mathrm{NO}_{2}, \mathrm{OBn}, \mathrm{OCF}_{3}, \mathrm{OMe}, \mathrm{OCH}_{2}-$ cyclopropyl, $-\mathrm{OCH}_{2} \mathrm{O}$-,

(i) $\mathrm{NaOEt}$, $\mathrm{EtOH}$, r.t., 24 h; (ii) $\mathrm{NaOMe}, \mathrm{MeOH}$, r.t., 48 h; (iii) piperidine, $\mathrm{MeOH}$, reflux, $30 \mathrm{~min}$; (iv) NaOEt, EtOH, r.t., $12 \mathrm{~h}$ or $55^{\circ} \mathrm{C} 1-2 \mathrm{~h}$ or reflux 10-15 min / NaOMe, $\mathrm{MeOH}$, reflux, $18 \mathrm{~h}$

Scheme 4. Synthesis of 2-SCs 19-23 through the condensation of 2-methylchromones with benzaldehydes. nitrochromones and benzaldehydes in dry methanol at reflux together with a few drops of piperidine afforded the corresponding 3-nitro-2-styrylchromones 22 in 70-80\% yields. ${ }^{[33]} \mathrm{A}$ wide range of $2-S C s$ 23, unsubstituted at C-3, were obtained by condensation between substituted 2-methylchromones and appropriate benzaldehydes in alkaline medium with ethanol as solvent at room temperature, ${ }^{[25,34-36]} 55^{\circ} \mathrm{C}^{[37]}$ or boiling temperature $^{[38]}$ or even in methanol at reflux ${ }^{[39,40]}$ (Scheme 4).

\subsection{Aldol Condensation/Cyclodehydrogenation}

A more general approach in the preparation of 2-SCs requires an initial step in which a typical base-catalyzed aldol condensation between a 2'-hydroxyacetophenone and an appropriate cinnamaldehyde affords the corresponding 2'-hydroxycinnamylideneacetophenone $\mathbf{2 4}$. The reaction is usually carried out in the presence of an aqueous solution of sodium hydroxide in ethanol ${ }^{[25,41-43]}$ or methanol ${ }^{[44,45]}$ but the use of barium hydroxide in ethanol ${ }^{[46-48]}$ or methanol ${ }^{[49]}$ and LiHMDS [lithium bis(trimethylsilyl)amide] in $\mathrm{THF}^{[50]}$ has also been reported (Scheme 5). These 2'-hydroxycinnamylideneacetophenones $\mathbf{2 4}$ undergo cyclodehydrogenation to give the corresponding 2-SCS $(E)-\mathbf{2 5}$ in the presence either of a catalytic amount of iodine in DMSO ${ }^{[41,42,44-47,51-54]}$ or of $\mathrm{SeO}_{2}$ in pentanol or xylenes. ${ }^{[55]}$ Under the former conditions, $\gamma$-substituted 2'-hydroxycinnamylideneacetophenones $\mathbf{2 4}$ afford not only the $E$ isomers $(E)-\mathbf{2 5}$ but also the $Z$ isomers ( $Z$ ) -25 in small amounts (11-15\% yields, Scheme 5). ${ }^{[44,53]}$

It is noteworthy that Cheema et al. synthesized a few $2^{\prime}$ hydroxycinnamylideneacetophenones that could not be converted into 2-styrylchromanones either in boiling alcoholic sulfuric acid or on prolonged contact with an alkaline solution. ${ }^{[25]}$ Another interesting aspect is the reaction time in the oxidative cyclization of 2'-benzyloxy-6'-hydroxycinnamylideneacetophenone $\mathbf{2 7}$ carried out in the presence of a catalytic amount of iodine in DMSO (Scheme 6). Heating the reaction mixture at reflux for $30 \mathrm{~min}$ led to the formation of the corresponding 5-benzyloxy-2-styrylchromone (28) whereas on heating at reflux for $2 \mathrm{~h}$, removal of the 5-benzyloxy group also occurred and 5-hydroxy-2-styrylchromone (4) was isolated. ${ }^{[51,54]}$ Hydrogen iodide, formed during the cyclization step, reacts with the benzyl group of the 2-SC to form benzyl iodide, which undergoes oxidation promoted by DMSO to afford benzaldehyde and to regenerate hydrogen iodide to continue the debenzylation process (Scheme 6). In the presence of one equivalent of iodine or bromine, a subsequent electrophilic substitution reaction occurs, with the corresponding 6,8-(diiodo or dibromo)-5-hydroxy-2-styryl-chromones $\mathbf{2 9}$ being obtained. ${ }^{[52]}$ On the other hand, the presence of 0.5 equiv. of the halogen led to a mixture of C-6 or C-8 monohalogenated 5hydroxy-2-styrylchromones $\mathbf{3 0}$ (Scheme 6). ${ }^{[54]}$

Other methodologies for preparing 3-hydroxy-2-styrylchromones $\mathbf{2 6}$ have also been developed, with 2'-hydroxycinnamylideneacetophenones $\mathbf{2 3}$ being treated with hydrogen peroxide in alkaline medium ${ }^{[43,49,50,55-58]}$ or diethylamine in a 2:1 mixture of DMSO/1,4-dioxane ${ }^{[47]}$ (Scheme 5). In these cases pyranone ring closure occurs through an Algar-Flynn-Oyamada 
$\mathrm{R}^{1}=\mathrm{H}, \mathrm{Br}, \mathrm{Cl}, \mathrm{I}, \mathrm{Me}, \mathrm{OBn}, \mathrm{OBz}, \mathrm{OH}, \mathrm{OMe}$

$\mathrm{R}^{2}=\mathrm{H}, \mathrm{Me}, \mathrm{OMe}$

$\mathrm{R}^{3}=\mathrm{H}, \mathrm{Et}$, hexyl, Me

$\mathrm{R}^{4}=\mathrm{H}, t \mathrm{Bu}, \mathrm{Cl}, \mathrm{OBn}, \mathrm{OMe}$<smiles>[R]C(=C1C=CC([R1])C=C1)c1cc(=O)c2ccc([R1])cc2o1</smiles><smiles>[R4]C(=Cc1ccccc1)c1cc(=O)c2ccccc2o1</smiles>

(ii)

(iii)

O Z-25<smiles>[R]C(COCC(=O)c1ccc([R1])cc1)=C([R])c1ccc([R1])cc1</smiles>

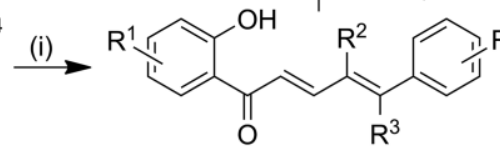

24

(i) $\mathrm{NaOH}$ (aq.), $\mathrm{MeOH}$ or EtOH / $\mathrm{Ba}(\mathrm{OH})_{2}, \mathrm{EtOH} / \mathrm{LiHMDS}$, THF

(ii) $\mathrm{I}_{2}$ (cat.), $\mathrm{DMSO} / \mathrm{SeO}_{2}$ in pentanol or xylenes

(iii) when $\mathrm{R}^{2}$ is substituted, $\mathrm{I}_{2}$ (cat.), DMSO, reflux, $30 \mathrm{~min}$

(iv) $\mathrm{H}_{2} \mathrm{O}_{2}, \mathrm{NaOH}$ or $\mathrm{KOH}, \mathrm{MeOH}$ or EtOH or THF/MeOH (1:1) / $\mathrm{H}_{2} \mathrm{O}_{2}, \mathrm{NEt}_{2}, \mathrm{DMSO} / 1$,4-dioxane (2:1)

Scheme 5. Synthesis of 2-SCs 25-26 through aldol condensation between 2'-hydroxyacetophenones and cinnamaldehydes followed by cyclodehydrogenation reactions. LiHMDS = lithium bis(trimethylsilyl)amide.

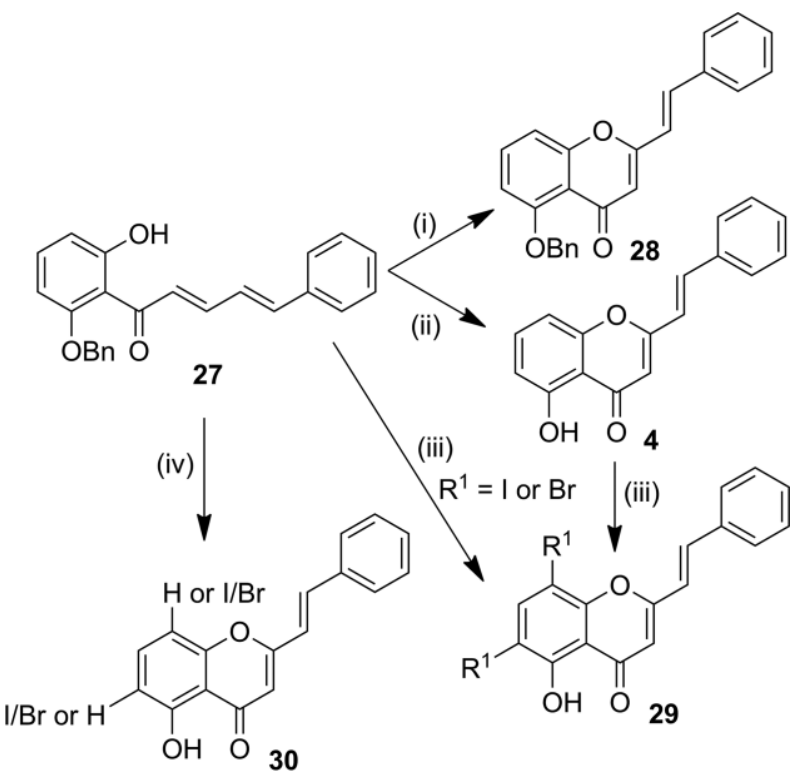

(i) $\mathrm{I}_{2}$ (cat.), DMSO, reflux, 30 min

(ii) $\mathrm{I}_{2}$ (cat.), DMSO, reflux, $2 \mathrm{~h}$

(iii) $\mathrm{I}_{2}$ or $\mathrm{Br}_{2}$ (1 equiv.), DMSO, reflux, 30 min

(iv) $\mathrm{I}_{2}$ or $\mathrm{Br}_{2}$ ( 0.5 equiv.), DMSO, reflux, $30 \mathrm{~min}$

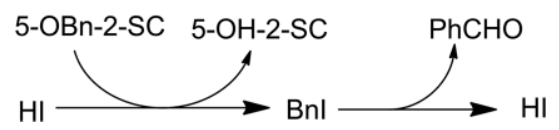

Scheme 6. Reaction behaviour of 2'-benzyloxy-6'-hydroxycinnamylideneacetophenone (27) in the presence of different amounts of iodine/bromine in DMSO and reaction times.

(AFO) process. Although there is some controversy about the mechanism of the AFO reaction ${ }^{[59-61]}$ and the involvement or not (pathways B and C) of epoxide formation (Scheme 7), we can state that in the presence of base, cyclization of 2'-hydroxycinnamylideneacetophenones $\mathbf{2 3}$ with simultaneous hydroxyl- ation promoted by hydrogen peroxide led to 3-hydroxy-2chromanones, which were subsequently oxidized to 3-hydroxy2-styrylchromones 26.

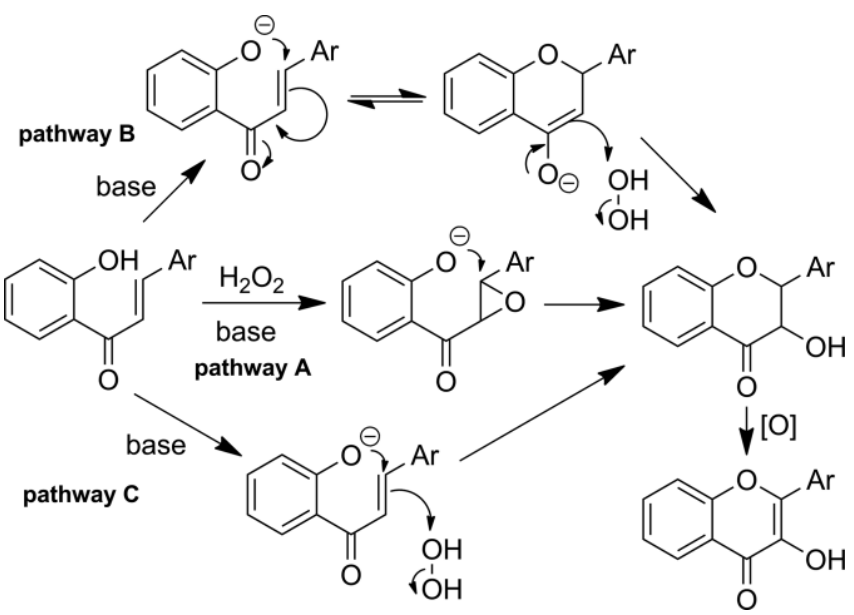

Scheme 7. Proposed mechanism for the Algar-Flynn-Oyamada (AFO) reaction of chalcones.

\subsection{Baker-Venkataraman Rearrangement}

This is the most common and general method for the preparation of a large variety of 2-SCs. The classical approach involves a three-step sequence: (i) condensation of appropriate 2'hydroxyacetophenones with cinnamoyl chlorides, (ii) base-promoted Baker-Venkataraman rearrangement ${ }^{[62,63]}$ of the formed esters 31 into the 5-aryl-3-hydroxy-1-(2-hydroxyaryl)penta-2,4dien-1-ones 32 (in equilibrium with the corresponding diketone form), and (iii) cyclodehydration to afford the desired 2-SCs 33 (Scheme 8). The cinnamoyl chlorides used in the esterification step may be commercially available or can be prepared in situ by treatment of the corresponding cinnamic acids with phosphoryl chloride in dry pyridine at room temperature or 60- 
$90{ }^{\circ} \mathrm{C}^{[7,8,18,19,32,45,47,64-74]}$ or with $\mathrm{N}, \mathrm{N}$-dicyclohexylcarbodiimide (DCC) in the presence of a catalytic amount of 4-pyrrolidinepyridine (4-PPy) in dichloromethane at room temperature. ${ }^{[13,75]}$ Transposition of the cinnamoyl group from the 2'-position to position 2 of the acetophenone occurs in the presence of potassium hydroxide with $\mathrm{DMSO}^{[13,18,19,7,8,32,67-69,71,73]}$ or pyridine $^{[47,64,70,73,74]}$ as solvent, of sodium hydride in THF at reflux ${ }^{[8,45,65]}$ or under less conventional conditions such as potassium carbonate in acetone at reflux ${ }^{[66]}$ or sodium hydroxide in DMSO at room temperature. ${ }^{[75]}$ The last step was originally achieved in a strongly acidic medium (sulfuric acid in acetic acid at reflux), but this is rarely used nowadays. ${ }^{[64,70,74]}$ It has been replaced by use of milder reagent systems, including the use of a few drops of diluted hydrochloric acid in acetic acid, ${ }^{[73]}$ of $p$-toluenesulfonic acid (PTSA) in DMSO ${ }^{[13,18,19,7,8,65,67,68,72]}$ or of a catalytic amount of iodine in DMSO. ${ }^{[13,18,8,45,68]}$ Individual attempts with use of concentrated sulfuric acid in ethanol at reflux, ${ }^{[66]}$ grinding with phosphorus pentoxide under solventfree conditions ${ }^{[76]}$ and with potassium carbonate in water under classical heating at reflux or under microwave-assisted conditions $^{[77]}$ have also been reported (Scheme 8).
Nikam et al. performed a three-step approach to the synthesis of 2-SCs and compared the use of classical heating conditions and of ultrasound irradiation. The results indicate that shorter reaction times and better yields are obtained with the ultrasound-assisted method. ${ }^{[73]}$

The synthesis of 3-substituted 2-SCs by this three-step strategy involves the previously mentioned penta-2,4-dien-1-ones. Various 3-bromo-2-styrylchromones $\mathbf{3 4}$ were obtained when 5aryl-3-hydroxy-1-(2-hydroxyaryl)penta-2,4-dien-1-ones 32 were treated with bromine in 1,4-dioxane ${ }^{[64]}$ and with phenyltrimethylammonium tribromide (PTT) in THF at room temperature (Scheme 9). ${ }^{[32,69]}$ Treatment of penta-2,4-dien-1-ones with $\mathrm{N}$ bromosuccinimide (NBS) in $\mathrm{CCl}_{4}$ in the presence of benzoyl peroxide produces inseparable mixtures of 2-bromopenta-4-en1,3-diones 35 and 3-bromo-2-styrylchromones $34\left(\mathrm{R}^{3}=\mathrm{Br}\right)$. Cyclodehydration of the former compounds with sulfuric acid in acetic acid gives solely 3-bromo-2-styrylchromones $34\left(\mathrm{R}^{3}=\right.$ $\mathrm{Br})$. The isolation of 2-bromopenta-4-en-1,3-diones 35 was also achieved when penta-2,4-dien-1-ones were treated with bromine either in a 1:1 mixture of 1,4-dioxane/DMF or in acetic acid in the presence of acetate buffer at room tempera-

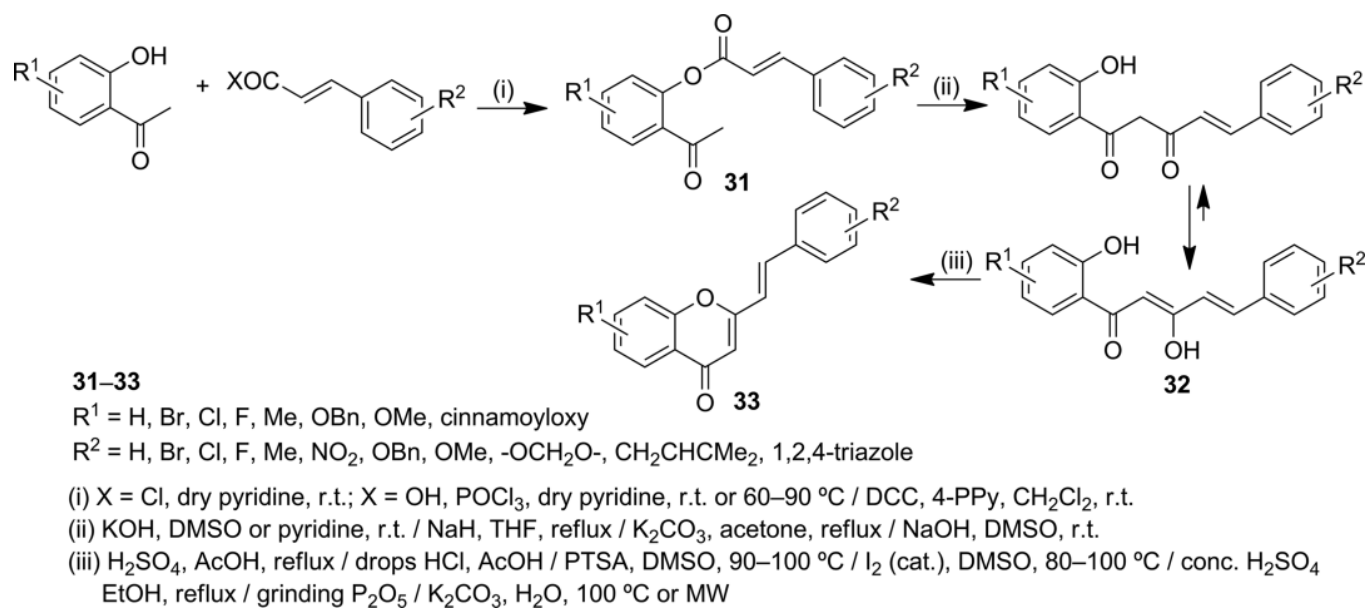

Scheme 8. Three-step approaches to the synthesis of 2-SCs through Baker-Venkataraman rearrangement. DCC $=N, N^{\prime}$-dicyclohexylcarbodiimide, 4-PPy $=4$ pyrrolidinepyridine, PTSA = $p$-toluenesulfonic acid, $\mathrm{MW}=$ microwave irradiation.

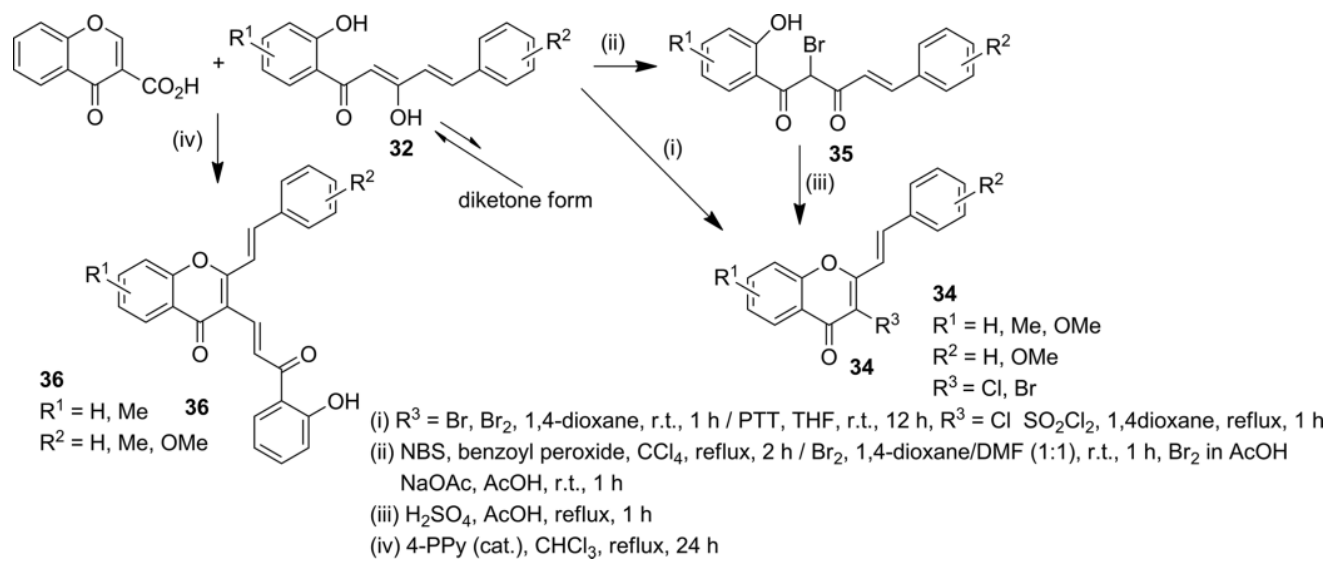

Scheme 9. Synthesis of 3-substituted 2-SCs 34 and 36 through cyclodehydration of the corresponding 5-aryl-3-hydroxy-1-(2-hydroxyaryl)penta-2,4-dien-1ones 32. PTT = phenyltrimethylammonium tribromide, NBS $=N$-bromosuccinimide. 


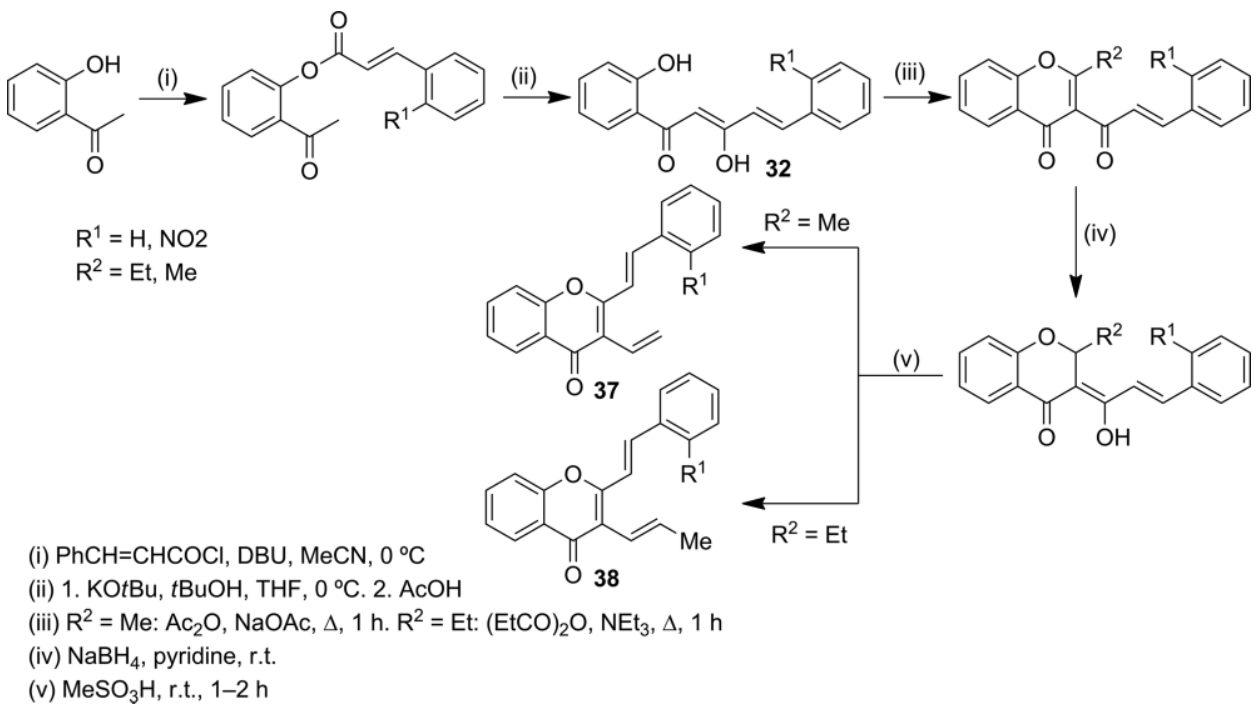

Scheme 10. Synthesis of 3-alkenyl-2-styrylchromones $\mathbf{3 7}$ and $\mathbf{3 8}$ through a multi-step approach starting from 2'-hydroxyacetophenone and cinnamoyl chlorides. DBU = 1,8-diazabicyclo[5.4.0]undec-7-ene.

ture. ${ }^{[64,78]}$ Moreover, treatment of penta-2,4-dien-1-ones 32 with sulfuryl chloride in 1,4-dioxane afforded 3-chloro-2-styrylchromones $34\left(\mathrm{R}^{3}=\mathrm{Cl}\right)$ in good yields. ${ }^{[64]}$ One-pot tandem reactions between penta-2,4-dien-1-ones 32 and chromone-3carboxylic acid in the presence of a catalytic amount of 4-PPy in chloroform at reflux provided a series of (2-hydroxyphenyl)3-oxoprop-1-enyl-2-styrylchromones 36 (Scheme 9). ${ }^{[75]}$

A unique multi-step approach allowed the preparation of a few 3-alkenyl-2-styrylchromones $\mathbf{3 7}$ and $\mathbf{3 8}$ through DBU-promoted condensation between 2'-hydroxyacetophenone and cinnamoyl chlorides in acetonitrile, Baker-Venkataraman rearrangement with potassium tert-butoxide in THF to afford the 5-aryl-3-hydroxy-1-(2-hydroxyphenyl)penta-2,4-dien-1-ones 32, acylation with $\mathrm{Ac}_{2} \mathrm{O}$ or $(\mathrm{EtCO})_{2} \mathrm{O}$ in basic medium, reduction with sodium borohydride in pyridine and finally dehydrative rearrangement mediated by $\mathrm{MeSO}_{3} \mathrm{H}$ at room temperature (Scheme 10). ${ }^{[79]}$

Two-step strategies involving Baker-Venkataraman rearrangement have appeared over the years. Makrandi and Kumari reported condensation between 2 '-hydroxyacetophenones and cinnamic anhydrides in the presence of tetrabutylammonium hydrogen sulfate in benzene/aqueous potassium carbonate biphasic medium to give 5-aryl-3-hydroxy-1-(2-hydroxyaryl)penta2,4-dien-1-ones 32 directly; after cyclodehydration by treatment with PTSA in DMSO these afforded the desired 2-SCs 33 in $65-80 \%$ yields. ${ }^{[80]} \mathrm{A}$ similar procedure used cinnamoyl chlorides in potassium carbonate/acetone medium, and cyclodehydration occurred in the presence of concentrated sulfuric acid in ethanol at reflux (Scheme 11). ${ }^{[49,81]}$

The synthesis of 3-cinnamoyl-5-hydroxy-2-styrylchromones 40 was achieved through a two-step procedure involving the condensation of $2^{\prime}, 6^{\prime}$-dihydroxyacetophenone with 2 equiv. of appropriate cinnamic acids in the presence of DCC and 4-PPy in dichloromethane at room temperature to afford the $2^{\prime}, 6^{\prime}$ dicinnamoyloxyacetophenones 39, which underwent cyclodehydration on treatment with potassium carbonate in dry pyridine at $120^{\circ} \mathrm{C}^{[13,82]}$ or under MW irradiation ${ }^{[83]}$ (Scheme 12).

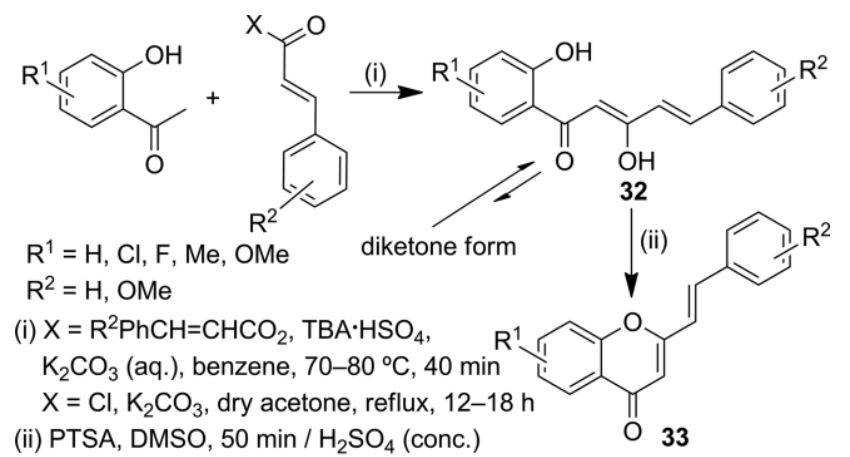

(ii) PTSA, DMSO, $50 \mathrm{~min} / \mathrm{H}_{2} \mathrm{SO}_{4}$ (conc.)

EtOH, reflux, $3 \mathrm{~h}$

Scheme 11. Two-step approaches to the synthesis of 2-SCs 33 through BakerVenkataraman rearrangement. TBA $=$ tetrabutylammonium.

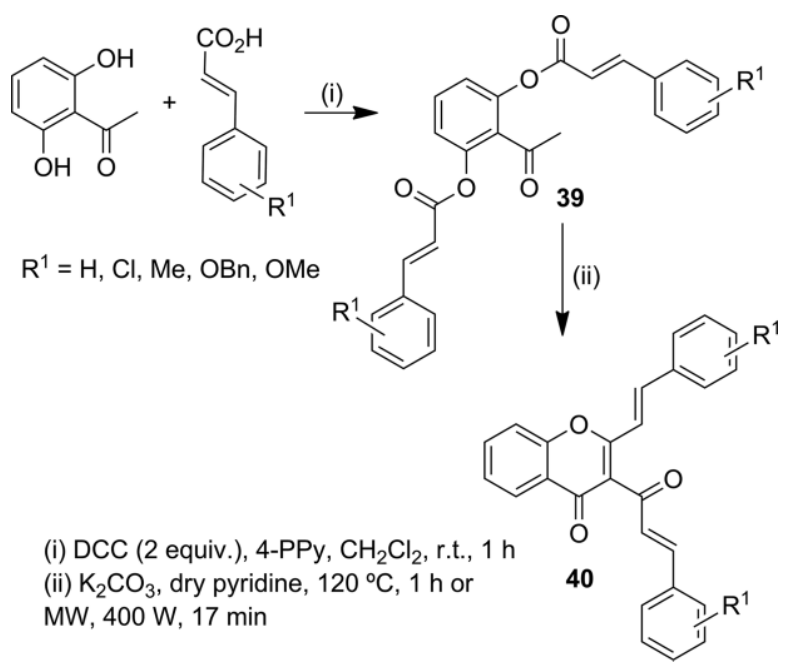

Scheme 12. Synthesis of 3-cinnamoyloxy-2-styrylchromones 40 through a two-step modified Baker-Venkataraman method.

A convenient one-pot synthesis of 3-cinnamoyl-5-hydroxy-7methyl-2-styrylchromones was accomplished when 2 ', $6^{\prime}$-di- 
hydroxy-4'-methylacetophenone was treated with 2 equiv. of cinnamoyl chlorides in the presence of potassium carbonate in acetone at reflux. The target 2 -SCs were obtained in quantitative yields on precipitation from the reaction medium, whereas after purification by column chromatography the yields were drastically decreased, due to crystallization during this process. ${ }^{[84]}$ On changing the acetophenone component to $2^{\prime}, 4^{\prime}$-dihydroxyacetophenone or $2^{\prime}, 4^{\prime}, 6^{\prime}$-trihydroxyacetophenone, 7cinnamoyloxy- or 5,7-dicinnamoyloxy-2-styrylchromones, respectively, were obtained. ${ }^{[85]}$

\section{Reactivity of 2-Styrylchromones}

The reactivity of the 2-SC nucleus towards photooxidative reactions, cycloadditions and nucleophilic addition reactions allowed the synthesis of a series of heterocyclic compounds. In a minor extension with the same goal, Heck reactions of 3-bromo derivatives, reduction and epoxidation reactions have also been performed.

\subsection{Photooxidative Reactions}

Photooxidative cyclization of 2-SCs 41 has been known since 1980, when Kumar et al. irradiated some derivatives in the pres- ence of iodine in dry benzene, in quartz vessels, with a medium-pressure mercury lamp for $50 \mathrm{~h}$. This gave rise to $12 \mathrm{H}$-benzo[a]xanthene-12-ones $\mathbf{4 2}$ in about $12 \%$ yield (Scheme 13). ${ }^{[86]}$ One year later, a similar approach under air and in the absence of iodine provided the same photoproducts in shorter periods of time (15-20 h) and better yields (1-31\% yield). ${ }^{[34]}$ One of us reported the synthesis of other derivatives<smiles>[R][R]1ccc(/C=C(\[R])c2cc(=O)c3ccc([Z13])cc3o2)cc1</smiles><smiles>[R2]/C(=C/C1=CC(=O)Oc2ccc([R1])cc2O1)c1ccccc1[R]</smiles>

$\mathrm{R}^{1}=\mathrm{H}, \mathrm{Me}, \mathrm{OMe}$

$\mathrm{R}^{2}=\mathrm{H}, \mathrm{Me}, \mathrm{Et}$, hexyl

$\mathrm{R}^{3}=\mathrm{H}, \mathrm{Br}, t \mathrm{Bu}, \mathrm{Cl}, \mathrm{Me}, \mathrm{OMe}$

(i) $\mathrm{I}_{2}$, dry benzene, $\mathrm{h} v$ (mercury lamp), $50 \mathrm{~h} /$ dry benzene, air, $\mathrm{h} v$ (mercury lamp), r.t. 15-20 h / $\mathrm{h} v$ (day light), $\mathrm{CHCl}_{3}$, r.t., 30-50 days<smiles></smiles>

42

Scheme 13. Synthesis of $12 \mathrm{H}$-benzo[ $a$ ]xanthen-12-ones $\mathbf{4 2}$ through photoirradiation of 2-SCs 41.<smiles>[R14]c1ccc(COc2c([R3])oc3ccc(Cl)cc3c2=O)cc1</smiles><smiles>[R1]c1ccc(C2([R])Oc3c(oc4ccc(Cl)cc4c3=O)C[C@H]2c2ccccc2)cc1</smiles><smiles>COc1c(C=Cc2ccccc2)oc2ccc(Cl)cc2c1=O</smiles><smiles></smiles><smiles>O=c1cc(/C=C/c2ccccc2)oc2ccc(Cl)cc12</smiles><smiles>O=C1c2cc(Cl)ccc2OC2(C=Cc3ccccc3)COC12</smiles>

$(14 \%)$

46
$(10 \%)$

47
$(7 \%)$

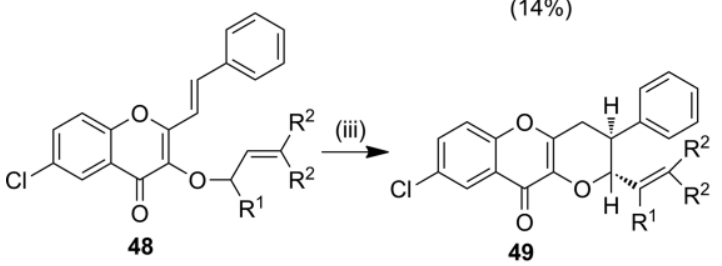

(11-15\%)

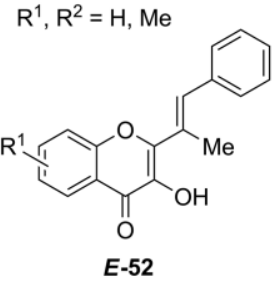

$\mathrm{R}^{1}=\mathrm{Cl}, \mathrm{OMe}$

(i) dry benzene, $h v$ (mercury lamp), $\mathrm{N}_{2}, 7 \mathrm{~h}$

(ii) dry $\mathrm{MeOH}, \mathrm{h} v, \mathrm{~N}_{2}, 90 \mathrm{~min}$

(iii) dry $\mathrm{MeOH}, \mathrm{h} v, \mathrm{~N}_{2}, 1 \mathrm{~h}$

(iv) dry $\mathrm{MeOH}, \mathrm{h} v$

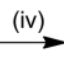<smiles>[R1]c1ccc2c(=O)c(O)c(/C(C)=C\c3ccccc3)oc2c1</smiles>

$(30-35 \%)$<smiles>[R]C1=COC2=C(/C=C/c3ccccc3)Oc3ccc(Cl)cc3C2(O)C1([R])[R]</smiles>

$(6-12 \%)$<smiles>[R]C1=CO[C@H]2C(=O)c3cc(Cl)ccc3O[C@]2(Cc2ccccc2)C1([R])[R]</smiles>

Scheme 14. Synthesis of several tricyclic and tetracyclic compounds through photoirradiation of 2-SCs. 
through a more eco-friendly methodology using daylight irradiation, chloroform as solvent and borosilicate glass vessels, in good yields (50-60\%, Scheme 13). ${ }^{[4,53]}$ These transformations involve isomerization, cyclization and oxidation reactions, in one-pot fashion.

Under photolytic conditions under nitrogen, (E)-3-benzyloxy6-methyl-2-styrylchromones 43, dissolved in benzene in a Pyrex glass reactor, underwent isomerization and cyclization to afford linear tricyclic tetrahydropyran[3,2-b]chromanones 44 in 20$29 \%$ yields. ${ }^{[87]}$ Under similar conditions, 3-methoxy-6-methyl-2styrylchromone 45, dissolved in dry methanol, furnished a mixture of the (Z)-2-SC (Z)-45, 3-demethoxylated 2-SC 46 and oxetanochromanone 47. The introduction of a 3-allyloxy or 3prenyloxy group instead of a 3-methoxy group, in 2-SC 48, led to a mixture of the two linear tricyclic photoproducts 49 and 51 and their angular counterpart 50 (Scheme 14). ${ }^{[43]} \mathrm{A}$ review on the photochemistry of chromones and bischromones, which includes the photoinduced $\mathrm{H}$-abstraction from 2-SCs, has been published. ${ }^{[88]}$

Irradiation of methanol solutions of (E)-3-hydroxy-2-( $\alpha$-methylstyryl)chromones $\mathbf{5 2}$ with a mercury lamp led to mixtures containing the corresponding $Z$ isomers ( $Z$ )-52, linear tricyclic $9 \mathrm{H}$-furo[3,2-b]chromen-9-ones $\mathbf{5 3}$ and angular fused tetracyclic 54 (Scheme 14). ${ }^{[89]}$

\subsection{Cycloaddition}

2-SCs can participate in a series of pericyclic reactions acting as dienes or dienophiles, as well as dipolarophiles, to provide other heterocyclic compounds. It was reported in 1954 that 2SCs act as dienes in Diels-Alder (DA) cycloaddition with maleic anhydride $(55, X=0)$ in boiling xylene, giving rise to the expected 3-aryl-1,2,3,9a-tetrahydro-9H-xanthen-9-one cycloadducts 56 (Scheme 15). ${ }^{[90]}$ Similar reactions were carried out with $N$-arylmaleimides $\left(X=N r^{1}\right.$, Scheme 15$),{ }^{[91]}$ dibenzoylethyl-

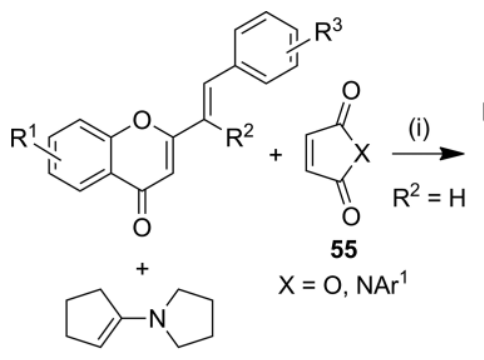

58

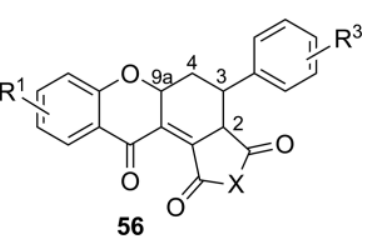

$\mathrm{R}^{1}=\mathrm{H}, \mathrm{Me}$

$\mathrm{R}^{3}=\mathrm{H}, \mathrm{OEt}, \mathrm{OMe},-\mathrm{OCH}_{2} \mathrm{O}-$

$\mathrm{Ar}^{1}=\mathrm{H}, \mathrm{Me}, \mathrm{OEt}, \mathrm{OMe}$

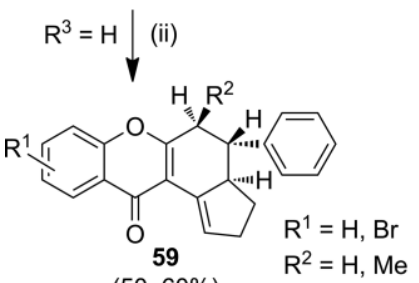

(50-60\%)

(i) boiling xylene; (ii) $95 \% \mathrm{EtOH}$, reflux

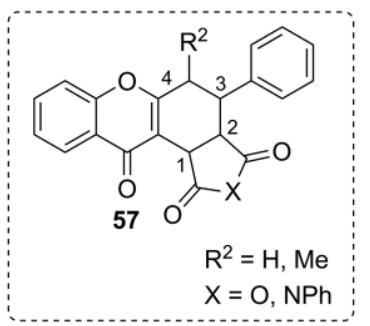

Scheme 15. 2-SCs as dienes in DA cycloaddition with maleic anhydride and $\mathrm{N}$-arylmaleimides. enes $^{[92]}$ and 1,4-benzoquinones ${ }^{[93,94]}$ as dienophiles, and the obtained cycloadducts were assumed also to be based on the 1,2,3,9a-tetrahydro-9H-xanthen-9-one moiety. However, studies conducted by Letcher and Yue in 1992 on the reactivity of 2-SCs with maleic anhydride and with $N$-phenylmaleimide and extensive spectroscopic characterization established that the adduct structures were those of the isomeric 1,2,3,4-tetrahydro$9 \mathrm{H}$-xanthen-9-ones 57 (Scheme 15). ${ }^{[95,96]}$ The formation of these compounds $\mathbf{5 7}$ was the result of a $[1,3]$ proton shift in the formed adducts $\mathbf{5 6}$, with the driving force of this isomerization being the stability of the reformed chromone moiety.

In addition, Letcher and Yue also studied the behaviour of an electron-rich dienophile in DA cycloaddition with 2-SCs. Use of one equimolar amount of the enamine 1-pyrrolidinylcyclopentene (58) in $95 \%$ ethanol at reflux led to the 1,2,3,4-tetrahydro-9H-xanthen-9-one cycloadducts 59 in $50-60 \%$ yields (Scheme 15). ${ }^{[97]}$ The trans stereochemistry of the obtained xanthones suggests that cycloaddition occurred through an exo-DA addition with inverse electron demand.

Other pyrrolidine enamines, formed in situ from acetone, butan-2-one and propanal in the presence of a catalytic amount of pyrrolidine, underwent [4+2] cycloaddition with a variety of $2-\mathrm{SCs}^{\left[{ }^{[9]}\right]}$ From acetone at reflux, several 3-aryl-1-methyl- $9 \mathrm{H}$ xanthen-9-ones 60 were obtained as main products $(56-76 \%$ yields, Scheme 16). 8-Methoxy-1-methylidene-3-phenyl-1,2,3,4tetrahydro-9H-xanthen-9-one (61) was also isolated as a single minor product, which was converted into the corresponding 8-methoxy-1-methyl-3-phenyl-9H-xanthen-9-one $\left(60, \mathrm{R}^{1}=5\right.$ OMe) upon treatment with a mixture of acetic acid/sulfuric acid. The mechanism involves formation of tetrahydroxanthones through [4+2] inverse-electron-demand cycloaddition, migration of the exocyclic double bond and dehydrogenation of the C-ring to yield the fully aromatized 1-methyl-9H-xanthen-9ones.

Two isomers were formed during pyrrolidine enamine preparation in situ from butan-2-one: 2-pyrrolidinobut-2-ene as the major product and 2-pyrrolidinobut-1-ene as a minor component. These underwent DA cycloaddition with 2-SCs to afford 3-aryl-2-methyl-1-methylidene-1,2,3,4-tetrahydro-9H-xanthen9-ones 62 (36-55\% yield) and small amounts of 3-aryl-1-ethyl9H-xanthen-9-ones 63 (13-16\% yield, Scheme 16). Treatment of the former tetrahydro-9H-xanthen-9-one $62\left(R^{1}=R^{2}=H\right)$ with strong acid for $3 \mathrm{~h}$ led to the corresponding 1,2-dimethyl3-phenyl-9H-xanthen-9-one (64) in almost quantitative yield (Scheme 16). An extension of this approach was applied to the reaction between the pyrrolidine enamine of propanal and the parent 2-SC, with the expected 2-methyl-3-phenyl-9H-xanthen9-one (65) being obtained in $12 \%$ yield (Scheme 16). ${ }^{[98]}$

Acting as dienophiles, a series of 2-SCs reacted with excess quantities of highly reactive o-benzoquinodimethane (66, formed in situ by the thermal extrusion of sulfur dioxide from 1,3-dihydrobenzo[c]thiophene 2,2-dioxide) in 1,2,4-trichlorobenzene at reflux to provide 2-(3-aryl-1,2,3,4-tetrahydronaphth2-yl)]chromones $67\left(\mathrm{R}^{1}=\mathrm{H}\right.$ ) in 76-89\% yields (Scheme 17). ${ }^{[99]}$ Complete aromatization of the obtained cycloadducts was achieved by a two-step approach involving benzylic bromination with NBS in the presence of benzoyl peroxide and subse- 


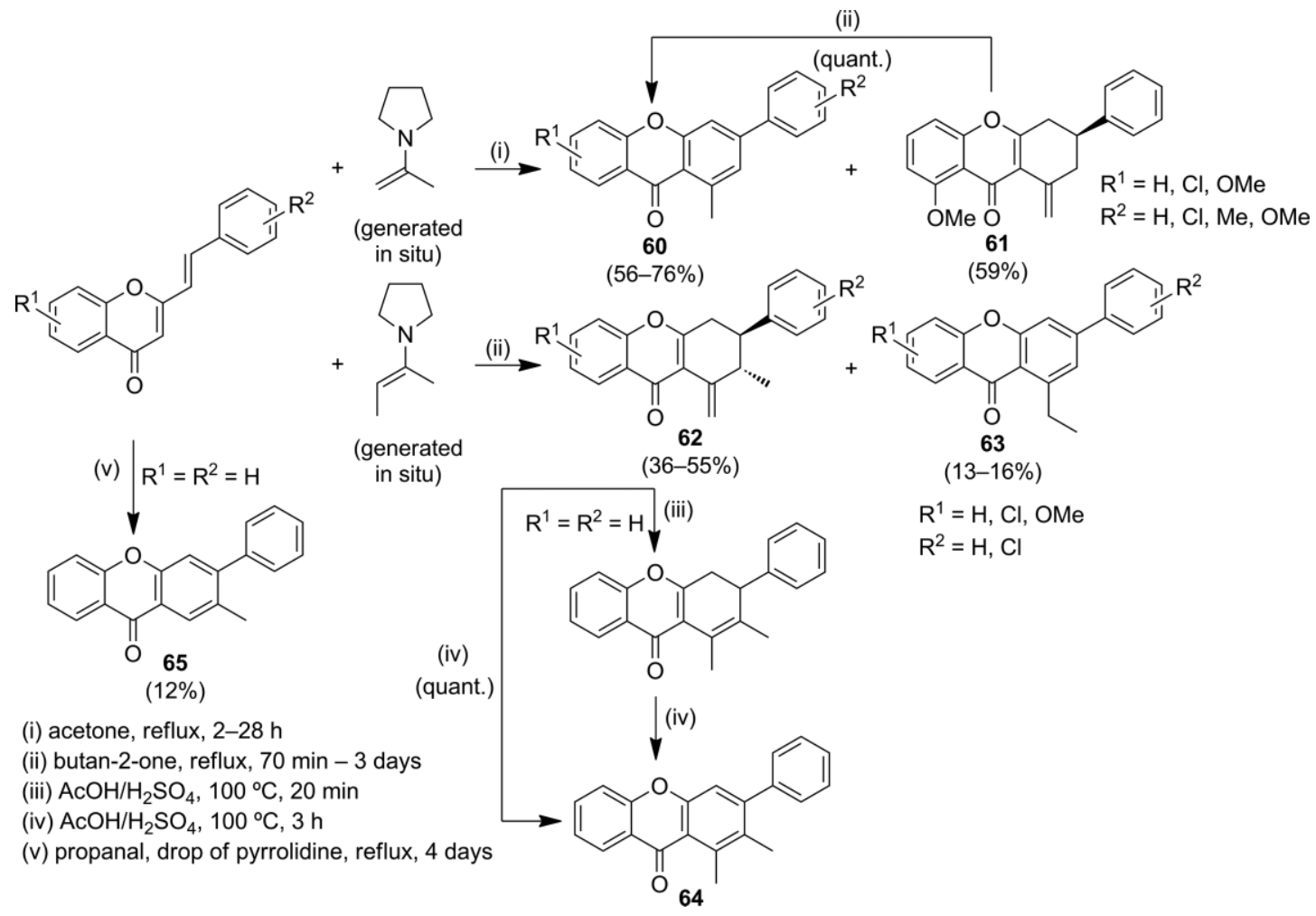

Scheme 16. 2-SCs as dienes in DA cycloaddition with pyrrolidine enamines.

quent dehydrobromination by heating the corresponding products in triethylamine at reflux. It is noteworthy that small amounts of brominated naphthylchromones $69\left(R^{1}=H\right)$ were also obtained and easily converted into the desired naphthylchromones $68\left(\mathrm{R}^{1}=\mathrm{H}\right)$ by treatment with ammonium formate and $\mathrm{Pd} / \mathrm{C}$ in methanol at reflux.

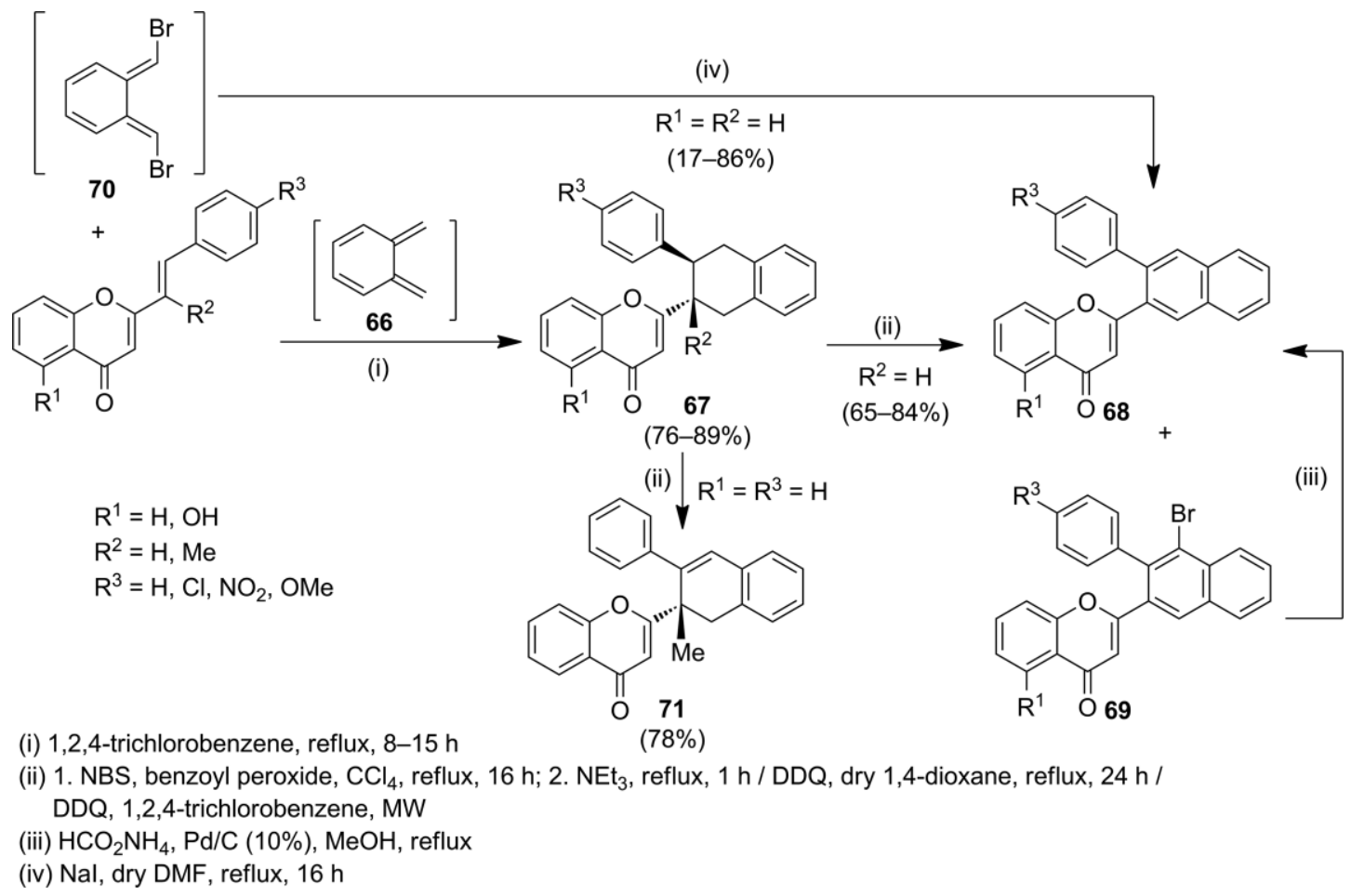

Scheme 17. 2-SCs as dienophiles in DA cycloaddition with symmetric o-benzoquinodimethanes. DDQ = 2,3-dichloro-5,6-dicyano-1,4-benzoquinone. 
To avoid the bromination step, o-benzoquinodibromodimethane (70), prepared in situ from $\alpha, \alpha, \alpha^{\prime}, \alpha^{\prime}$-tetrabromo-o-xylene, was allowed to react with 2-SCs in DMF at reflux; this also afforded naphthylchromones $\mathbf{6 8}\left(R^{1}=H\right)$, in a one-pot reaction. Complete aromatization of 1,2,3,4-tetrahydronaphthylchromone $67\left(R^{1}, R^{3}=H, R^{2}=M e\right)$ derived from 2-( $\alpha$-methylstyryl)chromone was not possible; instead, 2-(2-methyl-3-phenyl1,2-dihydronaphth-2-yl)]chromone $\mathbf{7 1}$ was isolated in $78 \%$ yield. ${ }^{[99]}$

Years later, Silva's group extended the study to reactions between o-benzoquinodimethane (66) and 2-SCs substituted at C5. The corresponding 1,2,3,4-tetrahydronaphthylchromones $\mathbf{6 7}$ $\left(\mathrm{R}^{1}=\mathrm{OH}\right)$ were prepared in lower yields (62-63\%). Subsequent dehydrogenation was performed in one-pot fashion with 2,3dichloro-5,6-dicyano-1,4-benzoquinone (DDQ) as oxidant in 1,4dioxane or 1,2,4-trichlorobenzene at reflux under MW irradiation (Scheme 17). Better yields and shorter reaction times were accomplished in the MW-assisted reactions. ${ }^{[100]}$

DA cycloaddition between 2-SCs and asymmetric pyrimidine o-quinodimethane 72, prepared in situ by thermal extrusion of sulfur dioxide from 4-methoxy-2-methyl-5,7-dihydrothieno[3,4d]pyrimidine 6,6-dioxide, led to mixtures of regioisomeric tetrahydroquinazoline-substituted chromones $\mathbf{7 3}$ and $\mathbf{7 4}$, with 2-(7-aryl-4-methoxy-2-methyl-5,6,7,8-tetrahydroquinazolin-6-yl)chromone derivatives $\mathbf{7 3}$ being the major isomers (Scheme 18). ${ }^{[101]}$ Variable amounts of the starting 2-SCs were also recovered (5-45\%).

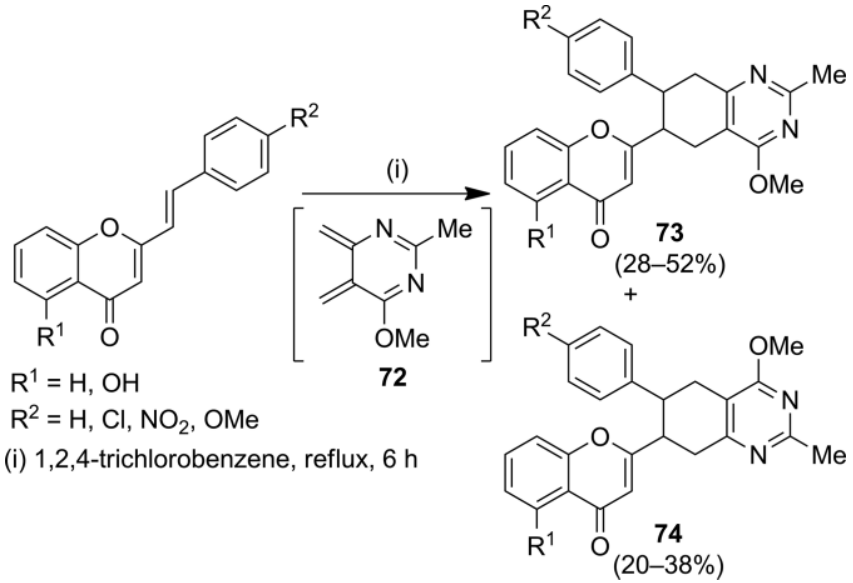

Scheme 18. 2-SCs as dienophiles in DA cycloaddition with asymmetric pyrimidine $o$-quinodimethane $\mathbf{7 2}$
Studies involving 2-SCs as dipolarophiles in 1,3-cycloaddition reactions with diazomethane or sodium azide have been reported. Treatment of 2-SCs with diazomethane in chloroform/ diethyl ether 1:3 mixtures at room temperature gave access mainly to 4-aryl-3-(chromon-2-yl)-2-pyrazolines 75 with higher $R_{\mathrm{f}}$ values (68-92\% yields) and, with lower $R_{\mathrm{f}}$ values, the 3 -aryl4-(chromon-2-yl)-1-pyrazoline regioisomers 76 (1-5\% yields, Scheme 19). ${ }^{[65]}$ Compounds 75 resulted from the isomerization of the formed cycloadducts $\mathbf{7 7}$ due to the acidity of $\mathrm{H}_{a}$ (Scheme 19).

The reactivity of the $C \alpha=C \beta$ double bond was also tested when 2-SCs were brominated with pyridinium tribromide in acetic acid at room temperature (Scheme 20). Mixtures of 3-bromo-2-styrylchromones $\mathbf{7 8}, \quad$ 2-(2-aryl-1,2-dibromoethyl)chromones 79 and 2-(2-aryl-1,2-dibromoethyl)-3-bromochromones $\mathbf{8 0}$ were isolated, according to the substitution pattern of the 2-SC. Dehydrobromination of 2-(2-aryl-1,2-dibromoethyl)chromones $\mathbf{7 9}$ with triethylamine in toluene at re-

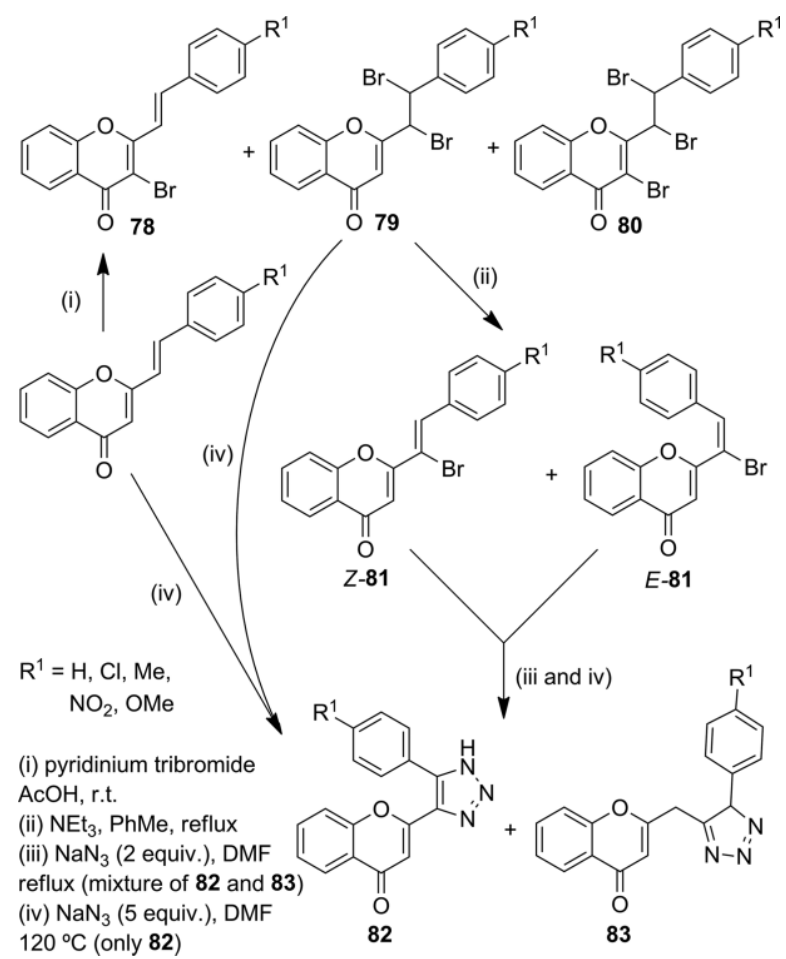

Scheme 20. 2-SC derivatives as dipolarophiles in the 1,3-cycloaddition reactions with sodium azide.

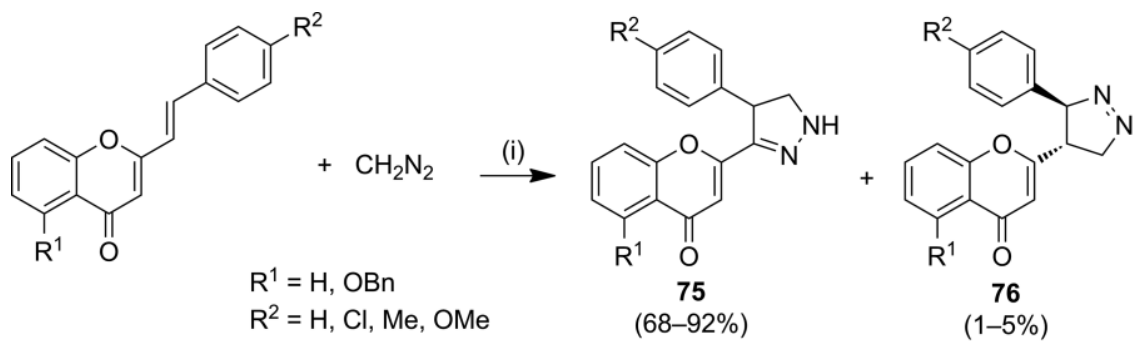

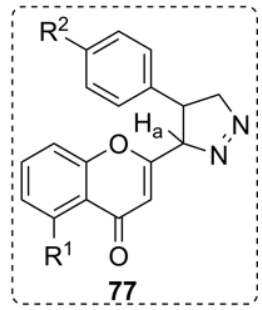

(i) $\mathrm{CHCl}_{3}$ /ethyl ether (1:3), r.t. 
flux gave both geometric isomers: (Z)-2-( $\alpha$-bromostyryl)chromones (Z)-81 as major products and (E)-2-( $\alpha$-bromostyryl)chromones $(E)-\mathbf{8 1}$ as minor products. Independent treatment of isomers (Z)-81 and (E)-81 with sodium azide (excess) in DMF at reflux afforded mainly 4(5)-aryl-5(4)-chromon-2-yl-1,2,3-triazoles 82 (30-40\% yield) and 1-aryl-5-(chromon-2-ylmethyl)tetrazoles 83, in $10-12 \%$ yields (Scheme 20$).^{[102]}$ Later on, the group improved the protocol to include other (Z)-2-( $\alpha$-bromostyryl)chromones ( $Z$ ) $\mathbf{8 1}$ by increasing the amount of sodium azide from 2 to 5 molar equivalents and decreasing the reaction temperature from reflux to $120{ }^{\circ} \mathrm{C}$ for $24 \mathrm{~h}$, with only 4(5)-aryl5(4)-chromon-2-yl-1,2,3-triazoles 82 being obtained, in 61-83\% yields. $^{[103]}$ Similar procedures with 2-SCs and 2-(2-aryl-1,2-dibromoethyl)chromones $\mathbf{7 9}$ as starting materials led to the same 4(5)-aryl-5(4)-chromon-2-yl-1,2,3-triazoles 82 in 47-65\% and $54-73 \%$ yields, respectively (Scheme 20). ${ }^{[103]}$ These one-pot reactions showed that bromination and dehydrobromination steps can be avoided in the preparation of 1,2,3-triazole derivatives of this type.

\subsection{Reactions with Nucleophiles}

The most common transformation of 2-SCs involving 1,4-addition reactions involves the use of hydrazines in order to prepare pyrazole derivatives. A series of (E)-3-(2-benzyloxy-6-hydroxyphenyl)-5-styrylpyrazoles $\mathbf{8 4}$ were thus obtained by treatment of 5-benzyloxy-2-styrylchromones with hydrazine hydrate or methylhydrazine in excess, in methanol at reflux for $24 \mathrm{~h}$, in moderate to good yields (Scheme 21). ${ }^{[104,105]}$ The proposed mechanism includes nucleophilic attack at C-2 of the 2-SC, ring opening and intramolecular hydrazone formation. A detailed investigation of the mother liquors from the reactions between 5-benzyloxy-2-styrylchromones and hydrazine hydrate in excess found not only the expected (E)-3-(2-benzyloxy-6-hydroxyphenyl)-5-styrylpyrazoles $\mathbf{8 4}$, but also the 3-(2-benzyloxy-6hydroxyphenyl)-5-(2-phenylethyl)pyrazoles 85 and 5-aryl3-(2-benzyloxy- $\beta, 6$-dihydroxystyryl)-2-pyrazolines $\mathbf{8 6 .}{ }^{[45]}$ The amounts of pyrazoles $\mathbf{8 4}$ increased with increasing amounts of hydrazine and/or on heating at reflux longer than necessary for the disappearance of the starting 2-SC. Reduction of the major pyrazoles 84 induced by diazene $\left(\mathrm{N}_{2} \mathrm{H}_{2}\right.$, formed by oxidation of hydrazine) explains the formation of the minor pyrazoles 85. 2Pyrazolines $\mathbf{8 6}$ arise from nucleophilic attack at C-2 of the 2-SC, ring opening and conjugate addition of hydrazine to $\mathrm{C}-\gamma$ of the formed $\alpha, \beta, \gamma, \delta$-doubly unsaturated opened system. A series of new 5(4)-aryl-4(5)-[3(5)-(2-hydroxyphenyl)-1H-pyrazol-5(3)-yl]$1 H$-1,2,3-triazoles $\mathbf{8 8}$ were prepared in moderate to good yields by treatment of 5(4)-aryl-4(5)-(chromon-2-yl)-1 $\mathrm{H}-1,2,3$-triazoles 87 with hydrazine hydrate in excess (5 molar equivalents) in methanol at $60{ }^{\circ} \mathrm{C}$ (Scheme 21). ${ }^{[106]}$

1,6-Conjugate additions of various nucleophiles to 2-SCs have been reported in a couple of papers. Thus, treatment of 2 -SCs with nitromethane in the presence of DBU at room temperature afforded the corresponding 2-(2-aryl-3-nitromethyl)chromones $\mathbf{8 9}$ in moderate to good yields. Subsequent reduction with tin powder and hydrochloric acid provided 2-substituted 4-arylpyrrole derivatives $\mathbf{9 0}$ in better yields than achieved with ammonium formate and $\mathrm{Pd} / \mathrm{C}$ (Scheme 22). ${ }^{[107]}$ On the other hand, a domino multicomponent 1,6-/1,6-/1,4-conjugate addition reaction between parent 2-SC (1) and nitromethane occurs under phase-transfer catalysis to give a mixture of<smiles></smiles>

Scheme 21. 1,4-Addition reactions of hydrazine derivatives to 2-SCs. 


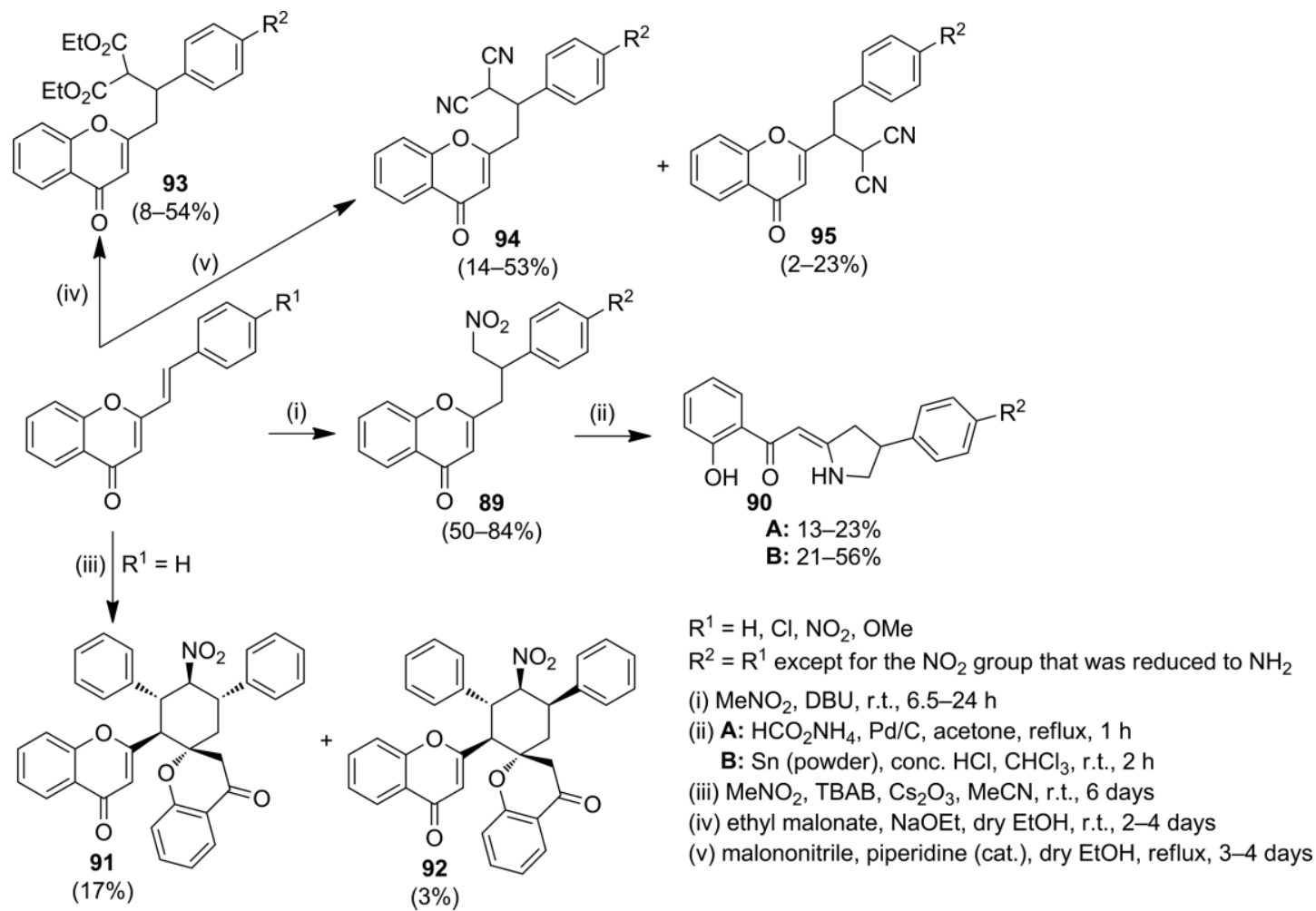

Scheme 22. Conjugate addition of nitromethane, ethyl malonate and malononitrile to 2-SCs. TBAB = tetrabutylammonium bromide.

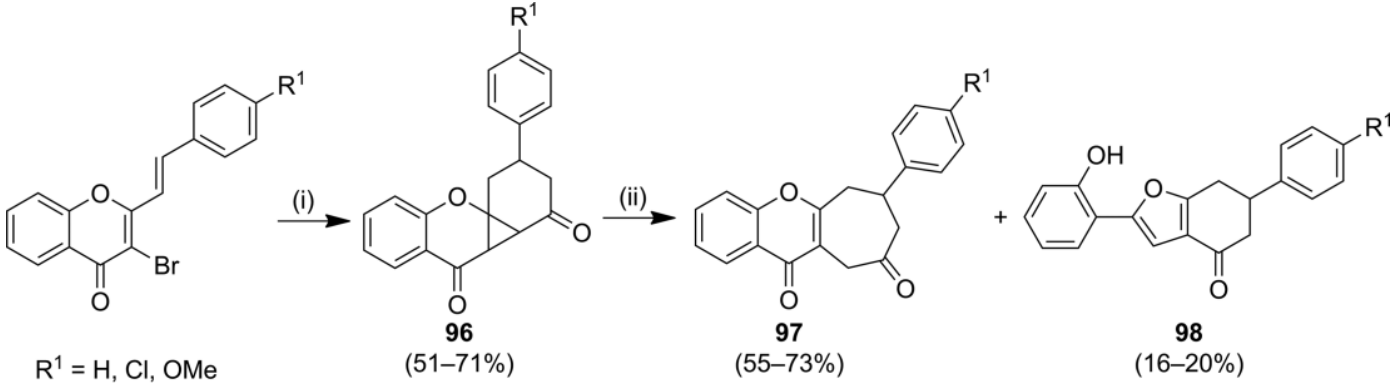

(i) pyrrolidine, acetone, $\mathrm{MW}, 100^{\circ} \mathrm{C}, 20 \mathrm{~min}$

(ii) $\mathrm{H}_{2} \mathrm{SO}_{4}$, glacial $\mathrm{AcOH}$, reflux, $2 \mathrm{~h}$

Scheme 23. Microwave-assisted tandem reactions between 3-bromo-2-styrylchromones and 1-(prop-1-en-2-yl)pyrrolidine for the synthesis of cyclohepta[b]chromene-9,11-diones $\mathbf{9 7}$ as major products.

pentasubstituted spirocyclohexanes 91 and 92 in poor yields and with recovery of an $11 \%$ yield of 2 -SC (1, Scheme 22). ${ }^{[108]}$

2-SCs underwent 1,6-conjugate addition with ethyl malonate in the presence of sodium ethoxide as base, giving rise to adducts 93 after 2-4 days, although in low yields (8-54\%). Use of malononitrile as nucleophile in the presence of a catalytic amount of piperidine in ethanol at reflux for 3-4 days afforded $\beta$-malononitrile adducts 94 (14-53\% yield) as major products, together with the $\alpha$-malononitrile derivatives 95 in poor yields (2-23\%) (Scheme 22). In these reactions it was also possible to recover some starting $2-\mathrm{SCs}^{\left[{ }^{[08]}\right.}$

The synthesis of cyclohepta[b]chromene-9,11-diones 96 occurred through microwave-assisted tandem 1,6-conjugate addition/Michael-initiated ring closure reactions between 3-bromo2-styrylchromones and 1-(prop-1-en-2-yl)pyrrolidine, prepared in situ from acetone and pyrrolidine, at $100{ }^{\circ} \mathrm{C}$ for $20 \mathrm{~min}$.
Subsequent acid-promoted cyclopropane ring-expansion led mainly to cyclohepta[b]chromene-9,11-diones 97; small amounts of benzofuran-4(5H)-ones 98 were also isolated (Scheme 23). ${ }^{[109]}$

\subsection{Miscellaneous Reactions}

Many synthetic routes require the protection of substituents in order to avoid the formation of by-products, to improve solubility in the reaction medium and to support the isolation and/ or purification processes. These protecting groups are usually removed in the last step to allow the synthesis of the target compounds. The most commonly used substituents for the protection of hydroxy groups in 2-SCs are the methyl and benzyl groups. Thus, demethylation of methoxy-substituted 2-styrylchromones is achieved by treatment with boron tribromide in 
dry dichloromethane, ${ }^{[40]}$ whereas debenzylation of benzyloxysubstituted 2-styrylchromones occurs in the presence of hydrogen bromine in acetic acid at reflux. ${ }^{[18,47]}$ Simultaneous demethylation and debenzylation was performed with use of an excess of aluminium chloride and sodium iodide in dry acetonitrile at room temperature for $12 \mathrm{~h} \cdot{ }^{[47]}$ The cleavage of cinnamoyl groups was achieved when 7-cinnamoyloxy- and 5,7dicinnamoyloxy-substituted 2-styrylchromones were hydrolyzed with $5 \%$ methanolic potassium hydroxide at reflux for 30 min. ${ }^{[85]} p$-Methoxybenzyl cleavage was carried out in the presence of trifluoroacetic acid in dichloromethane at room temperature for $30 \mathrm{~min}^{[37]}$

Boron tribromide also promoted simultaneous demethylation and cyclization of 3-cinnamoyl-5-hydroxy-2-styrylchromones, to afford (E)-3-aryl-4-benzylidene-8-hydroxy-3,4-dihydro$1 \mathrm{H}$-xanthene-1,9(2H)-diones $\mathbf{9 9}{ }^{[83]}$ and of 5,7-dimethoxy-8prenyl-2-styrylchromones to give (E)-5-hydroxy-8,8-dimethyl2-styryl-9,10-dihydropyrano[2,3-f]chromen-4(8H)-ones $\quad \mathbf{1 0 0}^{[19]}$ (Scheme 24).

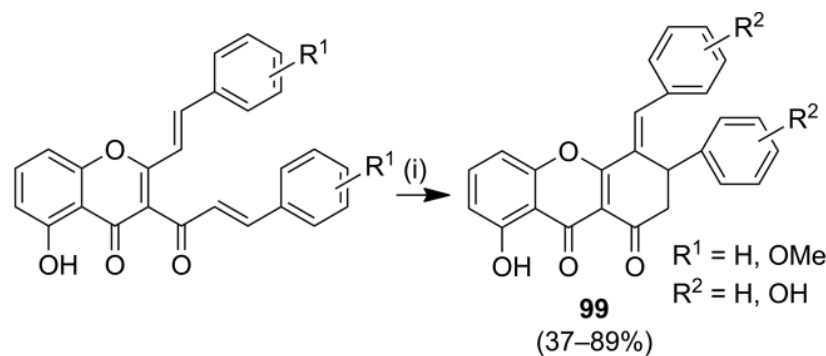<smiles></smiles>

Scheme 24. Simultaneous demethylation and cyclization of 2-SCs promoted by boron tribromide.

A series of 2-cinnamoyl-3(2H)-benzofuranones 101 were synthesized when 3-bromo- and 3-chloro-2-styrylchromones underwent rearrangement in the presence of potassium hydroxide in ethanol at reflux (Scheme 25). ${ }^{[64]}$ Reductive cyclization of 3-nitro-2-styrylchromones promoted by triethyl phosphite at reflux for $9 \mathrm{~h}$ led to pyrrolo[3,2-b]chromones $\mathbf{1 0 2}$ in $45-50 \%$ yields (Scheme 25). ${ }^{[33]}$

Several 2-(2-phenylethyl)chromones were synthesized by selective reduction of the double bond of the styryl group with hydrogen and activated $\mathrm{Pd} / \mathrm{C}$ in methanol at reflux ${ }^{[40]}$ or by addition of ammonium formate as hydrogen-transfer catalyst. ${ }^{[110]}$

The conversion of 6-bromo-2-styrylchromones into 6-iodo-2styrylchromones involves a two-step approach based on a bromo-to-tributyltin exchange reaction catalyzed by $\mathrm{Pd}^{0}$ and subsequent treatment with iodine in chloroform. The tributyltin intermediates can also undergo iododestannylation, in the pres-<smiles>[R]c1ccc(/C=C/c2oc3cc([R])c([R])cc3c(=O)c2/C=C/c2ccc([R10])cc2)cc1</smiles><smiles>[R]c1ccc(/C=C/c2oc3ccc([R])cc3c(=O)c2[N+](=O)[O-])cc1</smiles>

(i) $\mathrm{KOH}, \mathrm{EtOH}$, reflux, 2-3 h

(ii) $\mathrm{P}(\mathrm{OEt})_{3}$, reflux, $9 \mathrm{~h}$

$\mathrm{R}^{1}=\mathrm{H}, \mathrm{Me} ; \mathrm{R}^{2}=\mathrm{H}, \mathrm{Cl}, \mathrm{Me}, \mathrm{OMe}, \mathrm{NMe}_{2}$

Scheme 25. Cyclization reactions of 3-substituted 2-SCs.

ence of hydrogen peroxide as oxidant, in order to prepare 6radioiodinated 2-SCs. ${ }^{[70,74]}$

A large variety of 2,3-diarylxanthones 103 result as major products from reactions between polysubstituted 3-bromo-2styrylchromones and styrenes, mediated by palladium catalysts, in one-pot fashion. The proposed mechanism involves Heck coupling between brominated chromones and styrenes to form 2,3-distyrylchromones, in situ electrocyclization, [1,5]-sigmatropic hydrogen migration to give 3,4-dihydroxanthones and finally oxidation to achieve the corresponding 2,3-diarylxanthones 103. From this reaction it was also possible to isolate 2,3diaryl-3,4-dihydroxanthone intermediates 104 and 6,7-diaryl-1hydroxy-9H-xanthen-9-ones 105 when 3-bromo-5-methoxy2-styrylchromones were used as brominated derivatives (Scheme 26). ${ }^{[31,32,69]}$ A few 2,3-diarylxanthone derivatives were also obtained through one-pot cyclization and oxidation reactions of 2,3-distyrylchromones in 1,2,4-trichlorobenzene at reflux. ${ }^{[32]}$

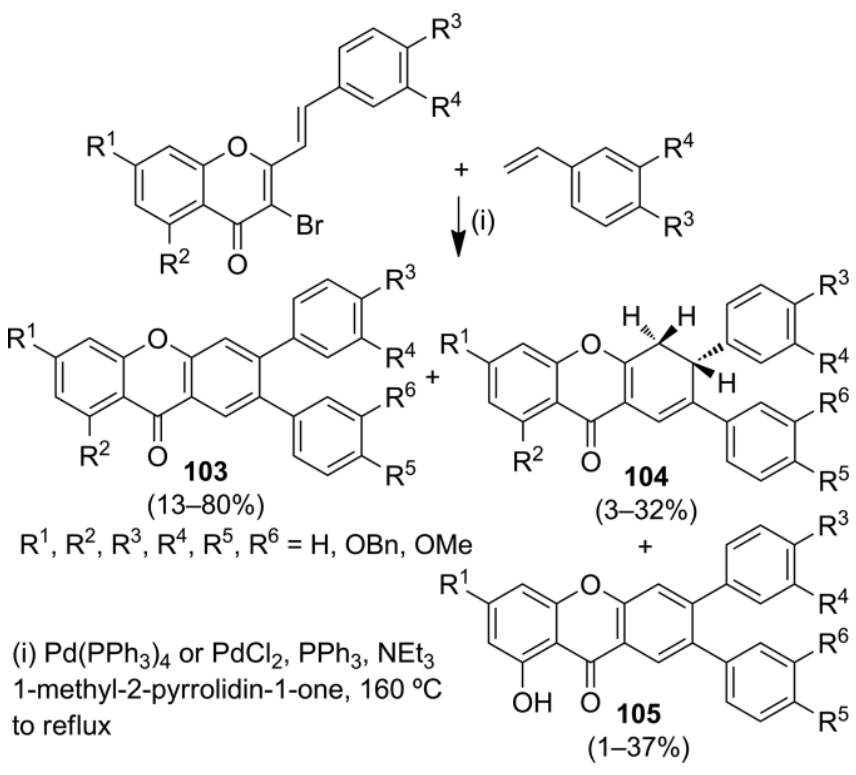

Scheme 26. One-pot reactions between 2-SCs and styrenes, promoted by palladium catalysts. 
The synthesis of 6,8-dibromo-5-hydroxy-2-styrylchromones or 5-hydroxy-6,8-diiodo-2-styrylchromones was achieved through halogenation of 5-hydroxy-2-styrylchromones with one equivalent of bromine or iodine, respectively, in DMSO at reflux. ${ }^{[52,54]}$ With use of 0.5 equiv. of the halogen, a mixture of monohalogenated 6- and 8-bromo/iodo derivatives was obtained. ${ }^{[54]}$

Regioselective epoxidation of 2-SCs with hydrogen peroxide and iodosylbenzene in the presence of the Jacobsen catalyst (107) led to the synthesis of a range of $\alpha, \beta$-epoxy-2-styrylchromones 106 (Scheme 27). Although the best results were accomplished with iodosylbenzene as oxidant, poor yields are generally obtained, due to the low reactivity of 2-SCs and the unstable character of the epoxides formed. ${ }^{[111]}$

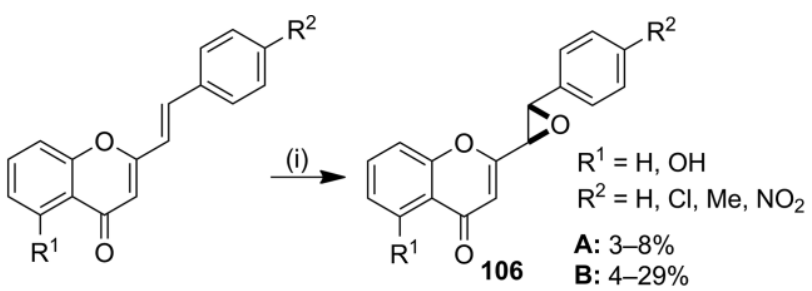

(i) A: catalyst 107, $\mathrm{H}_{2} \mathrm{O}_{2}$ (aq.) $30 \%$, 1-methylimidazole, $1: 1 \mathrm{CH}_{2} \mathrm{Cl}_{2} / \mathrm{MeOH}, 40^{\circ} \mathrm{C}$ 2 days

B: catalyst 107, PhlO, pyridine $\mathrm{N}$-oxide, acetonitrile, r.t., $12 \mathrm{~h}$

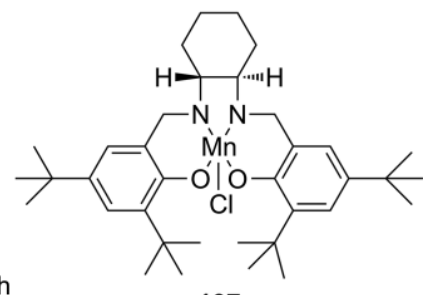

107

Scheme 27. Epoxidation of 2-SCs with hydrogen peroxide and iodosylbenzene in the presence of the Jacobsen catalyst (107).

\section{Biological Properties of 2-Styrylchromones}

A variety of biological properties have been ascribed to 2-SCs, including antiallergic, ${ }_{1}^{[12]}$ anti-inflammatory, ${ }^{[113]}$ antioxidant, $^{[114-118]}$ antitumor ${ }^{[10-12,36,39,119]}$ and antiviral, ${ }^{[49,58,66]}$ as well as affinity and selectivity for $A_{3}$ adenosine receptors, ${ }^{[38]}$ reviewed by Gomes et al. in 2010. ${ }^{[120]}$ Here we update the biological assessment of 2-SCs, but also describe some studies not considered in that review. According to the literature available upon 2010 we thus consider four main topics in this chapter: antioxidant and anti-inflammatory, antimicrobial, antitumor and neuroprotective activities.

\subsection{Antioxidant and Anti-Inflammatory Activities}

Pawar reported the DPPH radical scavenging activity of a range of substituted 2-SCs 108-116 (Figure 4), which showed significant inhibitory activity (60-71\%). However, it is difficult to evaluate the importance of these data because no positive control was used. ${ }^{[42]} 2$-SC has optimal features to be an excellent antioxidant, $^{[120]}$ so some of us synthesized the new 3-hydroxy-2styrylchromones 117-119, bearing catechol moieties in the $A$ and $B$ rings (Figure 4). The scavenging activity of these compounds against reactive oxygen species (superoxide anion radi- cal, hydrogen peroxide, hypochlorous acid, singlet oxygen and peroxyl radical) and reactive nitrogen species (nitric oxide and peroxynitrite anion) were structure- and concentration-dependent, with $\mathrm{IC}_{50}$ values in the micromolar range, and in most cases more efficient than the quercetin used as positive control. $^{[50]}$<smiles></smiles>

$1 R^{1}, R^{2}, R^{3}, R^{4}, R^{5}=H$

$108 R^{1}=I, R^{2}=C l, R^{3}, R^{4}, R^{5}=H$

$109 \mathrm{R}^{1}=\mathrm{I}, \mathrm{R}^{2}=\mathrm{Cl}, \mathrm{R}^{3}, \mathrm{R}^{4}=\mathrm{H}, \mathrm{R}^{5}=\mathrm{OMe}$

$110 R^{1}, R^{3}, R^{4}=H, R^{2}=B r, R^{5}=O M e$

$111 R^{1}=I, R^{2}, R^{3}, R^{4}, R^{5}=H$

$112 \mathrm{R}^{1}=\mathrm{I}, \mathrm{R}^{2}=\mathrm{Cl}, \mathrm{R}^{3}, \mathrm{R}^{5}=\mathrm{H}, \mathrm{R}^{4}=\mathrm{Me}$

$113 R^{1}=I, R^{2}, R^{3}, R^{4}=H, R^{5}=O M e$

$114 R^{1}=I, R^{2}, R^{3}, R^{4}=H, R^{5}=M e$

$115 \mathrm{R}^{1}, \mathrm{R}^{2}, \mathrm{R}^{4}=\mathrm{H}, \mathrm{R}^{3}=\mathrm{OH}, \mathrm{R}^{5}=\mathrm{OMe}$

$116 R^{1}, R^{2}, R^{3}, R^{5}=H, R^{4}=M e$

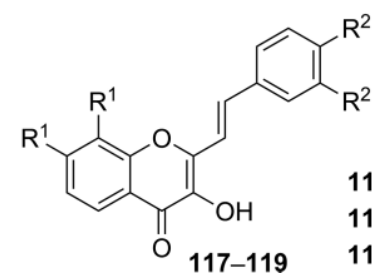

$117 \mathrm{R}^{1}=\mathrm{OH}, \mathrm{R}^{2}=\mathrm{OMe}$
$118 \mathrm{R}^{1}=\mathrm{OMe}, \mathrm{R}^{2}=\mathrm{OH}$
$119 \mathrm{R}^{1}, \mathrm{R}^{2}=\mathrm{OH}$

Figure 4. Structures of 2-SC derivatives 1, 4, 6 and 120-128 possessing antioxidant and anti-inflammatory activities.

During this period, studies of interference by 2-SCs in inflammatory pathways proceeded. Three of the twelve tested polyhydroxylated 2-SCs 1, 4, 6 and 120-128 (Figure 4) significantly inhibited NF-kB activation and reduced the production of proinflammatory cytokines/chemokines, with 5,3',4'-trihydroxy-2styrylchromone (6) being the most active compound. ${ }^{[121]}$

Hormothamnione diacetylated in the B-ring can be used in the treatment of inflammatory diseases, due to its inhibitory action on cell-cell adhesion between promyolocytic human leukaemia-60 (HL-60) cells and Chinese hamster ovary (CHO) intercellular cell adhesion molecule-1 (ICAM-1) cells. ${ }^{[122]}$

\subsection{Antimicrobial Activity}

In the first study on the antibacterial activity of $2-\mathrm{SCs}^{[72]}$ a series of fluorinated 2-SCs - compounds 129-138 (Figure 5) were prepared. They displayed higher antibacterial activity against Gram-positive than Gram-negative bacteria, with the activity being dependent on the number and position(s) of the fluorine substituent(s). The efficiency of these compounds follows the order: Bacillus subtilis more than Staphylococcus aureus and the single strain of Escherichia coli (ATCC 25922). Moreover, 3',5'-difluoro-2-styrylchromone (132) was active not only for E. coli (ATCC 25922) but also for E. coli (ATCC 35218). ${ }^{[72]}$ 
<smiles>[R][R]1ccc(/C=C/c2cc(=O)c3ccc([R])cc3o2)cc1</smiles>

129-138

$129 R^{1}=H, R^{2}=2^{\prime}-F$

$130 \mathrm{R}^{1}=\mathrm{H}, \mathrm{R}^{2}=3^{\prime}-\mathrm{F}$

$131 \mathrm{R}^{1}=\mathrm{H}, \mathrm{R}^{2}=4^{\prime}-\mathrm{F}$

$132 R^{1}=H, R^{2}=3^{\prime}, 5^{\prime}-$ di-F

$133 R^{1}=7-F, R^{2}=4^{\prime}-F$

$134 \mathrm{R}^{1}=7-\mathrm{F}, \mathrm{R}^{2}=\mathrm{H}$

$135 R^{1}=6-F, R^{2}=H$

$136 \mathrm{R}^{1}=\mathrm{H}, \mathrm{R}^{2}=4^{\prime}-\mathrm{OMe}$

$137 \mathrm{R}^{1}=\mathrm{H}, \mathrm{R}^{2}=3^{\prime}, 4^{\prime}$-di-OMe

$138 \mathrm{R}^{1}=\mathrm{H}, \mathrm{R}^{2}=3^{\prime}, 4^{\prime}-\mathrm{OCH}_{2} \mathrm{O}$<smiles>[R]c1cc2c(=O)cc(/C=C/c3ccc(-n4cncn4)cc3)oc2c([R])c1[R]</smiles>

139-146

$139 \mathrm{R}^{1}, \mathrm{R}^{2}, \mathrm{R}^{3}=\mathrm{H}$

$140 R^{1}, R^{2}=H, R^{3}=M e$

$141 R^{1}, R^{3}=M e, R^{2}=H$

$142 \mathrm{R}^{1}=\mathrm{H}, \mathrm{R}^{2}=\mathrm{Me}, \mathrm{R}^{3}=\mathrm{Cl}$

$143 R^{1}, R^{2}=H, R^{3}=F$

$144 \mathrm{R}^{1}, \mathrm{R}^{2}=\mathrm{H}, \mathrm{R}^{3}=\mathrm{Cl}$

$145 \mathrm{R}^{1}, \mathrm{R}^{3}=\mathrm{Cl}, \mathrm{R}^{2}=\mathrm{H}$

$146 \mathrm{R}^{1}, \mathrm{R}^{2}=\mathrm{H}, \mathrm{R}^{3}=\mathrm{Br}$<smiles>[R3]/C(=C\c1oc2cccc([R])c2c(=O)c1[R])c1ccc([R4])cc1</smiles>

$1,4,116,120,136,147-153$

$1 R^{1}, R^{2}, R^{3}, R^{4}=H$

$4 \mathrm{R}^{1}=\mathrm{OH}, \mathrm{R}^{2}, \mathrm{R}^{3}, \mathrm{R}^{4}=\mathrm{H}$

$116 R^{1}, R^{2}, R^{4}=H, R^{3}=M e$

$120 \mathrm{R}^{1}, \mathrm{R}^{2}, \mathrm{R}^{3}=\mathrm{H}, \mathrm{R}^{4}=\mathrm{OH}$

$136 R^{1}, R^{2}, R^{3}=H, R^{4}=O M e$

$147 \mathrm{R}^{1}, \mathrm{R}^{2}, \mathrm{R}^{3}=\mathrm{H}, \mathrm{R}^{4}=\mathrm{Cl}$

$149 R^{1}=O B n, R^{2}, R^{3}, R^{4}=H$

$150 R^{1}, R^{2}, R^{3}=H, R^{4}=M e$

$151 R^{1}, R^{3}, R^{4}=H, R^{2}=O H$

$152 \mathrm{R}^{1}, \mathrm{R}^{4}=\mathrm{H}, \mathrm{R}^{2}=\mathrm{OH}, \mathrm{R}^{3}=\mathrm{Me}$

$153 R^{1}, R^{3}, R^{4}=H, R^{2}=O M e$

Figure 5. Structures of 2-SC derivatives 1, 4, 116, 120 and 129-153, presenting antimicrobial activity.

Two years later, Nikam et al. evaluated the antibacterial (S. aureus, B. subtilis, E. coli and Pseudomonas aeruginosa) and antifungal (Candida albicans, Aspergillus niger and A. flavus) activities of 139-146, 2-SCs each bearing a 1,2,4-triazole ring as substituent at C-4' (Figure 5). ${ }^{[73]}$ Compounds 139 and 141 presented excellent activity against C. albicans (MIC $25 \mu \mathrm{g} \mathrm{mL}^{-1}$ ) in comparison with the standard fluconazole (MIC $50 \mu \mathrm{g} \mathrm{mL}^{-1}$ ). Docking studies indicated good binding interaction at the active site of fungal enzyme P-450 cytochrome lanosterol $14 \alpha$ demethylase, whereas good pharmacokinetics and drug-like properties were obtained from ADMET predictions.

A group of 2-SCs bearing substituents at C-3, C-5, C- $\alpha$ and C- $4^{\prime}$ - compounds 4, 116, 120, 136 and 147-153 (Figure 5) were screened for antinorovirus activity, together with parent 1. Of these, 5-hydroxy-2-styrylchromone (4) and 4'-methoxy-2styrylchromone (136) were the best agents, with $I C_{50}$ values around $7 \mu \mathrm{m}$. The mechanism of action of these compounds was also disclosed. ${ }^{[71]}$

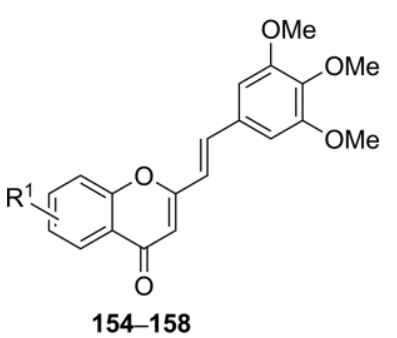

$\begin{aligned} 154 \mathrm{R}^{1} & =5-\mathrm{OMe} \\ 155 \mathrm{R}^{1} & =6-\mathrm{OMe} \\ 156 \mathrm{R}^{1} & =7-\mathrm{OMe} \\ 157 \mathrm{R}^{1} & =5,7-\text { di-OMe } \\ 158 \mathrm{R}^{1} & =7,8-\text { di-OMe }\end{aligned}$<smiles>[R][R]1ccc2oc(/C=C/c3cc(O)c(O)c(O)c3)cc(=O)c2c1</smiles>

$\begin{aligned} 159 \mathrm{R}^{1} & =5-\mathrm{OH} \\ 160 \mathrm{R}^{1} & =6-\mathrm{OH} \\ 161 \mathrm{R}^{1} & =7-\mathrm{OH} \\ 162 \mathrm{R}^{1} & =5,7-\text { di-OH } \\ 163 \mathrm{R}^{1} & =7,8-\mathrm{di}-\mathrm{OH}\end{aligned}$

\subsection{Antitumor Activity}

Natural platachromones A-D 7-10 (Figure 3) possess cytotoxic activity against human carcinoma cell lines with $\mathrm{IC}_{50}$ values ranging from 3.0 to $9.7 \mu \mathrm{M}$ against HepG2 (human hepatocarcinoma cell line) and KB (human epidermoid carcinoma cell line), although they are less active than taxol ( $\mathrm{IC}_{50}$ 0.04$0.05 \mu \mathrm{M})$, used as positive control. ${ }^{[15]}$ Lower sensitivity was observed for SMMC-7721 (human hepatocarcinoma cell line) and MDA-MB-231 (human breast cancer cell line), with $\mathrm{IC}_{50}$ values of 14.6-21.3 and 8.7-22.3 $\mu \mathrm{m}$, respectively.

Lin et al. demonstrated that polymethoxy-2-styrylchromones 154-158 are more active growth inhibitors of several carcinoma cells, especially gastric carcinoma cells, than their hydroxylated counterparts 159-163 (Figure 6). A common structural feature is the presence of a $3^{\prime}, 4^{\prime}, 5^{\prime}$-trimethoxy substituent, the 5-methoxylated derivative 154 being the most effective, with an $\mathrm{Gl}_{50}$ value of $1.3 \mu \mathrm{m}$. They also showed the importance of<smiles>[R]c1ccc(/C=C/c2cc(=O)c3ccc(O)c(CN(CCc4ccccc4)Cc4ccc(OC)cc4)c3o2)cc1</smiles><smiles>O=C(/C=C/c1c(/C=C/c2ccccc2)oc2ccccc2c1=O)c1ccccc1O</smiles>

$164 \mathrm{R}^{1}=\mathrm{H}$ $165 \mathrm{R}^{1}=4-\mathrm{OMe}$ $166 R^{1}=3,4-d i-O M e$ $167 \mathrm{R}^{1}=3-\mathrm{Br}$

Figure 6. Structures of 2-SC derivatives 154-169 presenting antitumor activity. 
the $C \alpha=C \beta$ double bond, reduction of which drastically decreased the compounds' growth inhibitory activity. ${ }^{[0]}$

The four 2-SC-based lavendustin A analogues 164-167 showed good anticancer activity against A-549 (human lung carcinoma), HCT-15 (human colon cancer cells) and KB cell lines (Figure 6). Compound 167 showed the highest activity $\left(\mathrm{IC}_{50}\right.$ $9.22 \pm 1.8 \mu \mathrm{g} \mathrm{mL}^{-1}$ ) against HCT-15, whereas 164 showed good activity against $\mathrm{A}-549$ and $\mathrm{KB}$ cell lines $\left(\mathrm{IC}_{50} 17.9 \pm 2.9\right.$ and $34.98 \pm 6.6 \mu \mathrm{g} \mathrm{mL}^{-1}$, respectively). ${ }^{[37,123]}$ Compound 168 (Figure 6) is a promising chemopreventive and therapeutic agent; selective inhibition of leukaemia K562 cell proliferation (IC 50 $4.5 \pm 1.9 \mu \mathrm{M}$, after $72 \mathrm{~h}$ ) was accomplished. ${ }^{[75]}$

Biochemical studies indicate the potential cancer chemopreventive activity of $3^{\prime}$-allyl-5,7,4'-trimethoxy-2-styrylchromone 169 (Figure 6) due to the induction of cytochrome $c$ release. ${ }^{[124]}$

\subsection{Neuroprotective Activity}

The protective effect of natural 6,4'-dihydroxy-3'-methoxy-2styrylchromone (5, Figure 3) at $10 \mu \mathrm{m}$ concentration was tested against glutamate-induced neurotoxicity in $\mathrm{P} 12$ pheochromocytoma cells and corticosterone-induced neurotoxicity in human U251 glioma cells. ${ }^{[14]}$ The results showed moderate activity in the former case $(58.3 \pm 2.8 \%)$ and absence of activity in preventing neurotoxicity in the last cell line tested. For comparison, the standard fluoxetine showed neuroprotective activity of $92.5 \pm 3.2$ and $93.7 \pm 2.1 \%$ at the same concentration for glutamate-induced and corticosterone-induced neurotoxicity, respectively. At the same concentration, the absence of neuroprotective activity in glutamate-induced neurotoxicity in primary cultures of rat cortical cells by natural 5-hydroxy-2-styrylchromone (4, Figure 3) was also reported. ${ }^{[12]}$ The natural 5,7,4'trihydroxy-2-styrylchromone (6, Figure 3) exhibited weak inhibitory activity against acetylcholinesterase with an $\mathrm{IC}_{50}$ value of $78.35 \pm 1.15 \mu \mathrm{M}$ in comparison with the positive control berberine $\left(I C_{50} 0.67 \pm 0.02 \mu \mathrm{M}\right)$. However, a good inhibitory activity against butyrylcholinesterase was observed $\left(\begin{array}{lll}6 & \mathrm{IC}_{50}\end{array}\right.$ $28.80 \pm 1.57 \mu \mathrm{m}$; berberine $\left.\mathrm{IC}_{50} 14.04 \pm 1.46 \mu \mathrm{M}\right)$ and also against the $\beta$-site amyloid precursor protein cleaving enzyme 1 (BACE1, $6 \mathrm{IC} 5_{50} 6.25 \pm 0.16 \mu \mathrm{m}$; quercetin $\mathrm{IC}_{50} 26.94 \pm 0.10 \mu \mathrm{m}$ ). ${ }^{[16]}$
Several 6-iodinated 2-SCs were synthesized and screened for their application as in vivo imaging probes of $\beta$-amyloid plaques in Alzheimer's disease. ${ }^{[70,74]}$ In an in vitro binding assay, high affinity towards preformed synthetic $A \beta(1-40)$ aggregates was observed for compounds [ $\left.{ }^{125} \mid\right] 170,\left[{ }^{125} \mid\right] 171$ and $\left[{ }^{125} \mid\right] 172$, with $K_{\mathrm{d}}$ values of $32.0 \pm 5.0,17.5 \pm 2.5$ and $8.7 \pm 2.7 \mathrm{~nm}$, respectively (Figure 7). In addition, in vivo biodistribution of radioactivity after intravenous administration in normal mice revealed high initial brain uptake and fast washout from the brain only for compounds $\left[{ }^{125} \mid\right] \mathbf{1 7 0}$ and $\left[{ }^{125} \mid\right] \mathbf{1 7 1}$, whereas the slow brain washout observed for $\left.{ }^{125} \mid\right] 172$ made it unsuitable to be used as in vivo $\beta$-amyloid imaging agent. ${ }^{[70]}$

Years later, a series of other 6-iodinated 2-SCs - compounds 173-180 in Figure 7 - mostly possessing an alkoxy group in the B-ring were tested in binding affinity assays. The inhibition constant $\left(K_{i}\right)$ values for the $A \beta$ aggregates varied from 21.9 to $553 \mathrm{nM}$, with compounds 174, 175 and 180 presenting the strongest binding interactions. Radioiodinated derivatives $\mathbf{1 8 1}$ and 182 (Figure 7) were prepared and showed high initial brain uptake and favourable clearance from the brain tissue of normal mice, in the biodistribution of radioactivity assay. Singlephoton emission computed tomography (SPECT) imaging and autoradiography helped to identify compound $\mathbf{1 8 2}$ as a more promising $A \beta$ imaging probe. ${ }^{[74]}$

Another study was performed to evaluate the potential of radioiodinated 2-SCs (Figure 7) for SPECT imaging of cerebral prion deposits. The results indicate that 2-SC 172 exhibited high in vitro binding affinity $\left(K_{\mathrm{d}} 24.5 \mathrm{nM}\right)$ and capacity $\left(B_{\max }=\right.$ $36.3 \mathrm{pmol} / \mathrm{nmol}$ protein) towards recombinant mouse prion protein aggregates and high accumulation in prion-proteinpositive regions of mouse brain infected with mouse-adapted bovine spongiform encephalopathy. ${ }^{[125]}$ Moreover, 2-SCs 174 and $\mathbf{1 7 5}$ revealed high binding affinity for recombinant mouse prion protein aggregates, with $K_{\mathrm{i}}$ values of 20.8 and $26.6 \mathrm{~nm}$, respectively. The similar radioiodinated derivatives 181 and 182 showed pronounced accumulation in prion-deposit-rich regions of mouse brain infected with mouse-adapted bovine spongiform encephalopathy. SPECT imaging and autoradiography data indicate that 2-SC $\mathbf{1 8 1}$ might be a potential imaging probe for monitoring prion deposit levels in the living brain. ${ }^{[125]}$

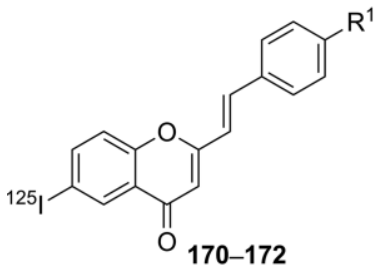

$$
\begin{aligned}
170 \mathrm{R}^{1} & =\mathrm{NH}_{2} \\
171 \mathrm{R}^{1} & =\mathrm{NHMe} \\
172 \mathrm{R}^{1} & =\mathrm{NMe}_{2}
\end{aligned}
$$<smiles>[R]c1ccc(/C=C/C2=CC(=O)C3=CC(I)C=CC3O2)cc1[R1]</smiles>

$173 \mathrm{R}^{1}, \mathrm{R}^{2}=\mathrm{H}$

$174 \mathrm{R}^{1}=\mathrm{H}, \mathrm{R}^{2}=\mathrm{OMe}$

$175 R^{1}, R^{2}=O M e$

$176 \mathrm{R}^{1}=\mathrm{H}, \mathrm{R}^{2}=\mathrm{OH}$

$177 \mathrm{R}^{1}=\mathrm{H}, \mathrm{R}^{2}=\mathrm{O}\left(\mathrm{CH}_{2}\right)_{2} \mathrm{OH}$

$178 \mathrm{R}^{1}=\mathrm{H}, \mathrm{R}^{2}=\left(\mathrm{OCH}_{2} \mathrm{CH}_{2}\right)_{2} \mathrm{OH}$

$179 \mathrm{R}^{1}=\mathrm{H}, \mathrm{R}^{2}=\left(\mathrm{OCH}_{2} \mathrm{CH}_{2}\right)_{3} \mathrm{OH}$

$180 \mathrm{R}^{1}=\mathrm{H}, \mathrm{R}^{2}=\mathrm{NMe}_{2}$<smiles>[R]c1ccc(/C=C/c2cc(=O)c3cc([123I])ccc3o2)cc1[R]</smiles>

$181 \mathrm{R}^{1}=\mathrm{H}, \mathrm{R}^{2}=\mathrm{OMe}$ $182 R^{1}, R^{2}=O M e$

Figure 7. Structures of 2-SC derivatives $\mathbf{1 7 0 - 1 8 2}$ possessing neuroprotective activity. 


\section{Conclusions}

The chemistry of 2-styrylchromones has been known since 1923 and continues to be relevant in the 21st century as a challenging topic of research in heterocyclic chemistry. Up until 2016, nine derivatives had been isolated from natural sources, and a huge variety of 2-styrylchromones had been synthesized by six main protocols, with aldol condensation/cyclodehydrogenation and Baker-Venkataraman rearrangement representing the most versatile approaches. Their involvement in photooxidative reactions, cycloadditions, reactions with nucleophiles and other transformations have been compiled and explored. A brief examination of the biological properties of 2-styrylchromones and structure-activity relationships is also included in this review.

\section{Acknowledgments}

Thanks are due to the Instituto Politécnico de Bragança and also to the University of Aveiro and the Formación en Centros de Trabajo, Ministerio de Educación y Ciencia (FCT, MEC) for the financial support of the QOPNA research unit (FCT UID/QUI/ 00062/2013) through national funds and, where applicable, cofinanced by the Fundo Europeu De Desenvolvimento Regional (FEDER), within the PT2020 Partnership Agreement. Thanks are also due to the Portuguese NMR Network.

Keywords: Oxygen heterocycles · Chromones · 2Styrylchromones · Synthetic methods · Reactivity · Biological activity

[1] R. S. Keri, S. Budagumpi, R. K. Pai, R. G. Balakrishna, Eur. J. Med. Chem. 2014, 78, 340-374.

[2] A. Gaspar, M. J. Matos, J. Garrido, E. Uriarte, F. Borges, Chem. Rev. 2014, 114, 4960-4992.

[3] K. S. Sharma, S. Kumar, K. Chand, A. Kathuria, A. Gupta, R. Jain, Curr. Med. Chem. 2011, 18, 3825-3852.

[4] H. A. Tawfik, E. F. Ewies, W. S. El-Hamouly, Int. J. Res. Pharm. Chem. 2014, 4, 1046-1085.

[5] F. Zammattio, J. D. Brion, L. Belachmi, G. Le Baut, J. Heterocycl. Chem. 1991, 28, 2013-2019.

[6] A. M. S. Silva, D. C. G. A. Pinto, J. A. S. Cavaleiro, A. Martínez, A. Castro, J. Elguero, J. Chem. Res. Synop. 2002, 162-164.

[7] M. Momin, D. Ramjugernath, N. A. Koorbanally, Magn. Reson. Chem. 2014, 52, 521-529.

[8] A. I. R. N. A. Barros, A. M. S. Silva, Magn. Reson. Chem. 2009, 47, 885-896.

[9] F. Zammattio, J. D. Brion, P. Hildgen, G. Le Baut, J. Chem. Res. Synop. 1995, 58-59.

[10] W. H. Gerwick, A. Lopez, G. D. van Duyne, J. Clardy, W. Ortiz, A. Baez, Tetrahedron Lett. 1986, 27, 1979-1982.

[11] W. Gerwick, J. Nat. Prod. 1989, 52, 252-256.

[12] J. S. Yoon, M. K. Lee, S. H. Sung, Y. C. Kim, J. Nat. Prod. 2006, 69, 290 291.

[13] D. C. G. A. Pinto, A. M. S. Silva, J. A. S. Cavaleiro, New J. Chem. 2000, 24, 85-92.

[14] L. Yang, L. Qiao, D. Xie, Y. Yuan, N. Chen, J. Dai, S. Guo, Phytochemistry 2012, 76, 92-97.

[15] C.-H. Yang, Y. Yang, J.-H. Liu, Phytochem. Lett. 2013, 6, 387-391.

[16] H. J. Jung, H. A. Jung, B.-S. Min, J. S. Choi, Chem. Pharm. Bull. 2015, 63, 955-960.

[17] P. Chaniad, C. Wattanapiromsakul, S. Pianwanit, S. Tewtrakul, Pharm. Biol. 2016, 54, 1077-1085.
[18] C. M. M. Santos, A. M. S. Silva, J. A. S. Cavaleiro, Eur. J. Org. Chem. 2003, 4575-4585.

[19] F. R. Baptista, D. C. G. A. Pinto, A. M. S. Silva, Synlett 2014, 25, 1116-1120.

[20] I. M. Helibron, H. Barnes, J. Chem. Soc. Trans. 1923, 123, 2559-2570.

[21] W. A. Price, A. M. S. Silva, J. A. S. Cavaleiro, Heterocycles 1993, 36, 26012612.

[22] A. M. S. Silva, D. C. G. A. Pinto, J. A. S. Cavaleiro, A. Levaí, T. Patonay, ARKIVOC 2004, vii, 106-123.

[23] D. Obrecht, Helv. Chim. Acta 1989, 72, 447-456.

[24] R. Robinson, J. Shinoda, J. Chem. Soc. 1925, 1973-1980.

[25] U. S. Cheema, K. C. Gulati, K. Venkataraman, J. Chem. Soc. 1932, 925933.

[26] A. Hercouet, M. Le Corre, Y. Le Floc'h, Synthesis 1982, 597-598.

[27] F. Zammattio, J. D. Brion, P. Ducrey, G. Le Baut, Synthesis 1992, 375-376.

[28] N. R. Ayyangar, R. A. Khan, V. H. Desphande, Tetrahedron Lett. 1988, 29, 2347-2348.

[29] R. Alonso, A. Brossi, Tetrahedron Lett. 1988, 29, 735-738.

[30] L. W. McGarry, M. R. Detty, J. Org. Chem. 1990, 55, 4349-4356.

[31] C. M. M. Santos, A. M. S. Silva, J. A. S. Cavaleiro, Synlett 2005, 3095-3098.

[32] C. M. M. Santos, A. M. S. Silva, J. A. S. Cavaleiro, Eur. J. Org. Chem. 2009, 2642-2660.

[33] C. Paparao, K. V. Rao, V. Sundaramurthy, Synthesis 1981, 234-236.

[34] K. C. Gulati, S. R. Seth, K. Venkataraman, J. Chem. Soc. 1934, 1765-1767.

[35] I. Yokoe, K. Higuchi, Y. Shirataki, M. Komatsu, Chem. Pharm. Bull. 1981, 29, 2670-2674.

[36] K. Momoi, Y. Sugita, M. Ishihara, K. Satoh, H. Kikuchi, K. Hashimoto, I. lokoe, H. Nishikawa, S. Fujisawa, H. Sakagami, In Vivo 2005, 19, 157-164.

[37] K. Y. Lee, D. H. Nam, C. S. Moon, S. H. Seo, J. Y. Lee, Y. S. Lee, Eur. J. Med. Chem. 2006, 41, 991-996.

[38] Y. Karton, J.-L. Jiang, X.-D. Ji, N. Melman, M. E. Olah, G. L. Stiles, K. A. Jacobson, J. Med. Chem. 1996, 39, 2293-2301.

[39] A. Y. Shaw, C.-Y. Chang, H.-H. Liau, P.-J. Lu, H.-L. Chen, C.-N. Yang, H.-Y. Li, Eur. J. Med. Chem. 2009, 44, 2552-2562.

[40] C. Lin, P.-J. Lu, C.-N. Yang, C. Hulme, A. Y. Shaw, Med. Chem. Res. 2013, 22, 2385-2394.

[41] J. A. S. Cavaleiro, J. Elguero, M. L. Jimeno, A. M. S. Silva, Chem. Lett. 1991, 20, 445-446.

[42] S. P. Pawar, D. D. Kondhare, P. K. Zubaidha, Med. Chem. Res. 2013, 22, 753-757.

[43] S. C. Gupta, M. Yusuf, S. Sharma, A. Saini, S. Arora, R. C. Kamboj, Tetrahedron 2004, 60, 8445-8454.

[44] A. M. S. Silva, D. C. G. A. Pinto, H. R. Tavares, J. A. S. Cavaleiro, M. L. Jimeno, J. Elguero, Eur. J. Org. Chem. 1998, 2031-2038.

[45] D. C. G. A. Pinto, A. M. S. Silva, J. A. S. Cavaleiro, C. Foces-Foces, A. L. Liamas-Saiz, N. Jagerovic, J. Elguero, Tetrahedron 1999, 55, 10187-10200.

[46] J. K. Makrandi, Seema, Indian J. Chem. 1991, 30B, 788-789.

[47] N. Jain, G. Gambhir, H. G. Krishnamurty, Indian J. Chem. 2001, 40B, 278283.

[48] M. Singhi, J. Pharm. Res. 2011, 4, 3040-3041.

[49] C. Conti, P. Mastromarino, P. Goldoni, G. Portalone, N. Desideri, Antiviral Chem. Chemother. Antivir. Chem. Chemother. 2005, 16, 267-276.

[50] J. L. C. Sousa, C. Proença, M. Freitas, E. Fernandes, A. M. S. Silva, Eur. J. Med. Chem. 2016, 119, 250-259.

[51] A. M. S. Silva, D. C. G. A. Pinto, J. A. S. Cavaleiro, Tetrahedron Lett. 1994, 35, 5899-5902.

[52] D. C. G. A. Pinto, A. M. S. Silva, J. A. S. Cavaleiro, Tetrahedron Lett. 1994, 35, 9459-9460.

[53] A. M. S. Silva, H. R. Tavares, J. A. S. Cavaleiro, Heterocycl. Commun. 1996 2, 251-254.

[54] D. C. G. A. Pinto, A. M. S. Silva, J. A. S. Cavaleiro, J. Heterocycl. Chem. 1996 33, 1887-1893.

[55] G. B. Marini-Bettòlo, Gazz. Chim. Ital. 1942, 72, 201

[56] F. M. Dean, V. Podimuang, J. Chem. Soc. 1965, 3978-3987.

[57] S. P. Dhoubhadel, S. M. Tuladhar, S. M. Tuladhar, P. P. Wagley, Indian J. Chem. 1981, 20B, 511-512.

[58] N. Desideri, P. Mastromarino, C. Conti, Antiviral Chem. Chemother. Antivir. Chem. Chemother. 2003, 14, 195-203.

[59] See ref. ${ }^{[56]}$

[60] M. Bennett, A. J. Burjke, W. I. O'Sullivan, Tetrahedron 1996, 52, $7163-$ 7178 
[61] S. Bhattacharyya, K. Hatua, RSC Adv. 2014, 4, 18702-18709.

[62] W. Baker, J. Chem. Soc. 1933, 1381-1389.

[63] H. S. Mahal, K. Venkataraman, J. Chem. Soc. 1934, 1767-1769.

[64] H. L. Gaggad, K. N. Wadodkar, B. J. Ghiya, Indian J. Chem. 1985, 24B, 1244-1247.

[65] D. C. G. A. Pinto, A. M. S. Silva, L. M. P. M. Almeida, J. A. S. Cavaleiro, A. Lévai, T. Patonay, J. Heterocycl. Chem. 1998, 35, 217-224.

[66] N. Desideri, C. Conti, P. Mastromarino, F. Mastropaolo, Antiviral Chem. Chemother. 2000, 11, 373-381.

[67] P. Filipe, A. M. S. Silva, P. Morlière, C. M. Brito, L. K. Patterson, G. L. Hug, J. N. Silva, J. A. S. Cavaleiro, J.-C. Mazière, J. P. Freitas, R. Santus, Biochem. Pharmacol. 2004, 67, 2207-2218.

[68] A. I. R. N. A. Barros, A. M. S. Silva, Heterocycl. Commun. 2006, 12, 141150

[69] C. M. M. Santos, A. M. S. Silva, J. A. S. Cavaleiro, Synlett 2007, 3113-3116.

[70] M. Ono, Y. Maya, M. Haratake, M. Nakayama, Bioorg. Med. Chem. 2007, 15, 444-450.

[71] J. R. Pereira, R. Cunha, D. C. G. A. Pinto, A. M. S. Silva, M. S. J. Nascimento, Bioorg. Med. Chem. 2010, 18, 4195-4201.

[72] M. Momin, D. Ramjugernath, H. Chenia, N. A. Koorbanally, J. Chem. 2013, article ID 436758, 13 pages.

[73] M. D. Nikam, P. S. Mahajan, M. G. Damale, J. N. Sangshetti, A. V. Chate, S. K. Dabhade, C. H. Gill, Lett. Drug Des. Discovery 2015, 12, 1-11.

[74] T. Fuchigami, A. Ogawa, Y. Yamashita, M. Haratake, H. Watanabe, M. Ono, M. Kawasaki, S. Yoshida, M. Nakayama, Bioorg. Med. Chem. Lett. 2015, 25, 3363-3367.

[75] O. Talhi, L. Brodziak-Jarosz, J. Panning, B. Orlikova, C. Zwergel, T. Tzanova, S. Philippot, D. C. G. A. Pinto, F. A. A. Paz, C. Gerhauser, T. P. Dick, C. Jacob, M. Diederich, D. Bagrel, G. Kirsch, A. M. S. Silva, Eur. J. Org. Chem. 2016, 965-975.

[76] D. Sharma, J. K. Makrandi, Green Chem. Lett. Rev. 2009, 2, 157-159.

[77] J. Pinto, V. L. M. Silva, A. M. G. Silva, A. M. S. Silva, Molecules 2015, 20, 11418-11431.

[78] B. D. Saraf, K. N. Wadodkar, Indian J. Chem. 1988, 27B, 771-772.

[79] D. S. Clarke, C. D. Gabbutt, J. D. Hepworth, B. M. Heron, Tetrahedron Lett. 2005, 46, 5515-5519.

[80] J. K. Makrandi, V. Kumari, Synth. Commun. 1989, 19, 1919-1922.

[81] B. P. Reddy, G. L. D. Krupadanam, J. Heterocycl. Chem. 1996, 33, 15611565.

[82] D. C. G. A. Pinto, A. M. S. Silva, J. A. S. Cavaleiro, Heterocycl. Commun. 1996, 2, 145-148.

[83] D. C. G. A. Pinto, A. M. L. Seca, S. B. Leal, A. M. S. Silva, J. A. S. Cavaleiro, Synlett 2011, 2005-2008.

[84] P. Königs, O. Neumann, O. Kataeva, G. Schnakenburg, S. R. Waldvogel, Eur. J. Org. Chem. 2010, 6417-6422.

[85] C. R. Reddy, G. L. D. Krupadanam, G. Srimannarayana, Indian J. Chem. 1987, 26B, 974-976.

[86] K. A. Kumar, G. Srimannarayana, Indian J. Chem. 1980, 19B, 615-617.

[87] S. C. Gupta, N. S. Yadav, S. N. Dhawan, Indian J. Chem. 1991, 30B, 790792

[88] R. Kumar, M. Yusuf, ARKIVOC 2006, xi, 239-264.

[89] S. Berar, U. Berar, S. C. Gupta, R. C. Kamboj, Chinese Chem. Lett. 2008, 19 , 780-782.

[90] A. Schonberg, A. Mustafa, G. Aziz, J. Am. Chem. Soc. 1954, 76, 45764577.

[91] A. Mustafa, M. I. Ali, J. Org. Chem. 1956, 21, 849-851.

[92] G. Aziz, J. Org. Chem. 1962, 27, 2954-2957.

[93] M. A.-F. Elkashef, F. M. E. Abdel-Megeid, K.-E. M. Mokhart, F. A. Gad, Acta Chim. Acad. Sci. Hung. 1975, 84, 319.

[94] H. Marona, Pol. J. Chem. 1979, 53, 1877.

[95] R. M. Letcher, T.-Y. Yue, J. Chem. Res. Synop. 1992, 248.

[96] R. M. Letcher, T.-Y. Yue, J. Chem. Res. Miniprint 1992, 2078-2089.

[97] R. M. Letcher, T.-Y. Yue, J. Chem. Soc., Chem. Commun. 1992, 1310-1311.
[98] A. S. Kelkar, R. M. Letcher, K.-K. Cheung, K.-F. Chiu, G. D. Brown, J. Chem. Soc. Perkin Trans. 1 2000, 3732-3741.

[99] A. M. S. Silva, A. M. G. Silva, A. C. Tomé, J. A. S. Cavaleiro, Eur. J. Org. Chem. 1999, 135-139.

[100] D. T. Patoilo, A. M. S. Silva, D. C. G. A. Pinto, A. C. Tomé, J. A. S. Cavaleiro, J. Heterocycl. Chem. 2007, 44, 1345-1350.

[101] D. T. Patoilo, A. M. S. Silva, D. C. G. A. Pinto, C. M. M. Santos, A. C. Tomé, J. A. S. Cavaleiro, Tetrahedron Lett. 2012, 53, 2722-2725.

[102] A. M. S. Silva, J. S. Vieira, J. A. S. Cavaleiro, T. Patonay, A. Lévai, J. Elguero, Heterocycles 1999, 51, 481-487.

[103] A. M. S. Silva, J. S. Vieira, C. M. Brito, J. A. S. Cavaleiro, T. Patonay, A. Lévai, J. Elguero, Monatsh. Chem. 2004, 135, 293-308.

[104] D. C. G. A. Pinto, A. M. S. Silva, J. A. S. Cavaleiro, Heterocycl. Commun. 1997, 3, 433-436.

[105] D. C. G. A. Pinto, A. M. S. Silva, J. A. S. Cavaleiro, J. Heterocycl. Chem. 2000, 37, 1629-1634

[106] J. P. A. Ferreira, V. L. M. Silva, J. Elguero, A. M. S. Silva, Tetrahedron Lett. 2013, 54, 5391-5394.

[107] E. M. P. Silva, A. M. S. Silva, J. A. S. Cavaleiro, Synlett 2011, 2740-2744.

[108] E. M. P. Silva, K. Grenda, I. N. Cardoso, A. M. S. Silva, Synlett 2013, 24, 2375-2382.

[109] J. L. C. Sousa, A. M. S. Silva, Synlett 2017, 28, 316-322.

[110] S. Goel, Shashi, J. K. Makrandi, Indian J. Chem. 2006, 45B, 535-536.

[111] C. M. M. Santos, A. M. S. Silva, J. A. S. Cavaleiro, T. Patonay, A. Lévai, J. Heterocycl. Chem. 2006, 43, 1319-1326.

[112] G. Doria, C. Romeo, A. Forgione, P. Sberze, N. Tibolla, M. L. Corno, G. Cruzzola, G. Cadelli, Eur. J. Med. Chem. 1979, 14, 347-351.

[113] A. Gomes, E. Fernandes, A. M. S. Silva, D. C. G. A. Pinto, C. M. M. Santos, J. A. S. Cavaleiro, J. L. F. C. Lima, Biochem. Pharmacol. 2009, 78, 171177.

[114] E. Fernandes, F. Carvalho, A. M. S. Silva, C. M. M. Santos, D. C. G. A. Pinto, J. A. S. Cavaleiro, M. L. Bastos, J. Enzyme Inhib. Med. Chem. 2002, $17,45-48$.

[115] E. Fernandes, M. Carvalho, F. Carvalho, A. M. S. Silva, C. M. M. Santos, D. C. G. A. Pinto, J. A. S. Cavaleiro, M. L. Bastos, Arch. Toxicol. 2003, 77 500-505.

[116] See ref. [67]

[117] A. Gomes, E. Fernandes, A. M. S. Silva, C. M. M. Santos, D. C. G. A. Pinto, J. A. S. Cavaleiro, J. L. F. C. Lima, Bioorg. Med. Chem. 2007, 15, 60276036.

[118] A. Gomes, O. Neuwirth, M. Freitas, D. Couto, D. Ribeiro, A. G. P. R. Figueiredo, A. M. S. Silva, R. S. G. R. Seixas, D. C. G. A. Pinto, A. C. Tomé, J. A. S. Cavaleiro, E. Fernandes, J. L. F. C. Lima, Bioorg. Med. Chem. 2009, 17, 7218-7226.

[119] J. Marinho, M. Pedro, D. C. G. A. Pinto, A. M. S. Silva, J. A. S. Cavaleiro, C. E. Sunkel, M. S. J. Nascimento, Biochem. Pharmacol. 2008, 75, 826835.

[120] A. Gomes, M. Freitas, E. Fernandes, J. L. F. C. Lima, Mini-Rev. Med. Chem. 2010, 10, 1-7.

[121] A. Gomes, J. P. Capela, D. Ribeiro, M. F, A. M. S. Silva, D. C. G. A. Pinto, C. M. M. Santos, J. A. S. Cavaleiro, J. L. F. C. Lima, E. Fernandes, Medicinal Chemistry 2015, 11, 560-566.

[122] S. Takamatsu, D. G. Nagle, W. H. Gerwick, Planta Med. 2004, 70, 127131.

[123] D. H. Nam, K. Y. Lee, C. S. Moon, Y. S. Lee, Eur. J. Med. Chem. 2010, 45, 4288-4292.

[124] F. Peixoto, A. I. R. N. A. Barros, A. M. S. Silva, J. Biochem. Mol. Toxicol. 2002, 16, 220-226.

[125] T. Fuchigami, Y. Yamashita, M. Kawasaki, A. Ogawa, M. Haratake, R. Atarashi, K. Sano, T. Nakagaki, K. Ubagai, M. Ono, S. Yoshida, N. Nishida, M. Nakayama, Sci. Rep. 2015, 5, 18440-18410.

Received: January 2, 2017 